\title{
Plant Virus Epidemiology: Applications and Prospects for Mathematical Modeling and Analysis to Improve Understanding and Disease Control
}

\author{
M. J. Jeger \\ Centre for Environmental Policy, Imperial College London, \\ Silwood Park, Ascot SL5 7PY, United Kingdom
}

L. V. Madden

Department of Plant Pathology, Ohio State University, Wooster, $\mathrm{OH} 44691$

\section{F. van den Bosch}

\author{
Computational and Systems Biology, Rothamsted Research, \\ Harpenden AL5 2JQ, United Kingdom.
}

In recent years, mathematical modeling has increasingly been used to complement experimental and observational studies of biological phenomena across different levels of organization (Chew et al. 2014). In this article, we consider the contribution of mathematical models developed using a wide range of techniques and uses to the study of plant virus disease epidemics. Our emphasis is on the extent to which models have contributed to answering biological questions and indeed raised questions related to the epidemiology and ecology of plant viruses and the diseases caused. In some cases, models have led to direct applications in disease control, but arguably their impact is better judged through their influence in guiding research direction and improving understanding across the characteristic spatiotemporal scales of plant virus epidemics. We restrict this article to plant virus diseases for reasons of length and to maintain focus even though we recognize that modeling has played a major and perhaps greater part in the epidemiology of other plant pathogen taxa, including vector-borne bacteria and phytoplasmas.

Typically, many models have been based on techniques for relating plant virus disease dynamics to comprehensive data sets on abiotic variables (known or assumed to have some effect on the disease cycle), and to datasets on biotic variables such as host plant growth and development, crop loss, cropping practices, and vector biology. Development and use of these models is characterized by the availability of observational and experimental data obtained in crop populations and is often used to forecast or retrospectively analyze disease dynamics. Techniques include regression, mixed model and generalized

${ }^{\dagger}$ Corresponding author: M. J. Jeger; E-mail: m.jeger@imperial.ac.uk Accepted for publication 27 November 2017.

(C) 2018 The American Phytopathological Society linear model analyses, and multivariate and time series analyses (Schabenberger and Pierce 2002).

Another type of model stems more from a conceptual model of what drives disease dynamics, which is then put in mathematical form and analyzed using standard mathematical or computational techniques. These types of model, the main focus of this article, are strategic in nature and not directly related to the immediate availability of relevant data, but serve a range of purposes and can subsequently be tested against data. These purposes include using models as calculation tools; for example, to calculate temporal and spatial rates of increase, derivation of epidemiological parameters that determine whether or not an epidemic will develop from low levels of initial infection, and in some cases, how to optimize from a range of disease control options against a set target. In this article, we place emphasis on how models can be developed and applied to analyze the likely success of disease control measures involving host resistance, cultural control (including roguing and exclusion through propagation methods), and vector control. This type of modeling approach can also be used to identify which parameters are critical to disease dynamics and control, to identify data gaps, and hence prioritize further research effort. In this approach, the basic reproduction number $R_{0}$ is a key epidemiological parameter (Box 1) that has been studied for animal diseases (Anguelov et al. 2012) and fungal plant diseases (van den Bosch et al. 2008), but less so for vector-borne diseases of plants (Shi et al. 2014; van den Bosch and Jeger 2017).

The basic reproduction number is a very flexible tool and can be derived in a wide range of contexts: for discrete-time plant virus models (Luo et al. 2015) as well as for better-studied continuous-time models (Jeger et al. 1998; Madden et al. 2000b); and used to evaluate virus disease control measures, e.g., when there is an impulsive or intermittent roguing of diseased plants (Gao et al. 2015). In some of these cases, a relatively high level of mathematical expertise is required. In other cases, the biological context is more intuitive. For 
example, a hybrid model including herbivore (consumer)-plant (resource) interaction in an epidemiological model, when the herbivore also vectors a plant pathogen, was analyzed (Nakazawa et al. 2012). The requirements for disease persistence depended on whether infection improves the plant nutritional quality and the herbivore feeds preferentially on the infected resource.

Trends in plant virus epidemiology have recently been reviewed by Jones (2014), including innovations in modeling that help to improve the ability to predict plant virus epidemics and to assist in delivering advice to end users through decision support systems. In general reviews of specific economically damaging virus diseases, there is often no consideration of the contribution that modeling can make to understanding epidemiology or to improve disease control. However, there is increasing recognition of the contribution modeling can make more generally in meeting the challenges in plant disease epidemiology (Cunniffe et al. 2015), including the specific case of vector-borne diseases. In this article, we consider the contribution that modeling has made in plant virus epidemiology, especially where this has led to new experimental studies. More importantly, we aim to identify key areas in which there are real opportunities for modeling to assist in addressing some of the key questions currently being addressed experimentally.
We aim to show how mathematical models of the various types described above have been used in plant virus epidemiology and identify areas in which there is a greater potential use in both understanding disease dynamics and using this understanding to underpin disease control. We start with perhaps the longest-established area, modeling abiotic and biotic relationships with disease dynamics, including crop loss. The need to go beyond purely temporal descriptions of disease progress is reflected in the trend to include spatial spread into models. This has led to a broad understanding of disease control options in general, and in particular the contribution that models can make to the deployment of host resistance (Jeger et al. 2017). This can also be seen in particular in models of cultural disease control based on roguing or removal of diseased plants, sometimes combined with their replacement by healthy plants; and in analyzing the influence of production systems on disease dynamics. There is also an attempt to model the impact of viruses on plant population and community dynamics in relatively unmanaged ecosystems, sometimes in an attempt to learn lessons that could be applied to crop production systems. As noted earlier, much modeling has been applied to what has been termed evolutionary epidemiology, including recent developments in modeling virulence evolution. An understanding of virus disease dynamics is incomplete without

\section{BOX 1 \\ The basic reproduction number, $\boldsymbol{R}_{0}$}

The basic reproduction number, $R_{0}$, is defined as the total number of infections arising from one newly infected individual introduced into a healthy population. Phrased differently, $R_{0}$ is the generation to generation multiplication factor of the number of infections in a host population when the incidence is very small. By very small, we mean that the density of infections is low enough that there is no pathogen-imposed limitation to pathogen increase (i.e., that spores or other units of infection do not come in contact with previously formed infections). If we start with $I_{0}$ infections, each of these infections produces $R_{0}$ new infections in the next generation, $I_{1}$. This next generation is thus given by $I_{1}=$ $R_{0} I_{1}$. Each infection in generation 1 also produces $R_{0}$ new infections in the following generation, $I_{2}$, and we have $I_{2}=R_{0} I_{1}=R_{0} R_{0} I_{0}=R_{0}^{2} I_{0}$. Following this reasoning, the number of infections in generation $n+1, I_{n+1}$, is given by

$$
I_{n+1}=R_{0} I_{n}
$$

Or,

$$
I_{n}=\left(R_{0}\right)^{n} I_{0}
$$

From these equations, it is clear that the basic reproduction number is a threshold parameter for epidemic development. When $R_{0}<1$, the number of infections decreases and the epidemic peters out, and when $R_{0}>1$, the number of infections increases and the epidemic takes off. The value $R_{0}=1$ is thus the threshold between the development of an epidemic and the disappearance of the infection from the population.

For pathogens that are transmitted by a vector, we have to take two populations into account. The density of infected host plants in generation $n$ is denoted by $I_{n}$, and the density of virus-carrying vectors by $Y_{n}$. We denote by $R_{\mid Y}$ the number of new infected hosts caused by one virus-carrying vector during its entire infected life, and by $R_{Y I}$ the number of new infected vectors resulting from one infected host during the host's entire infected life. The equations relating the densities of infected hosts and vectors in generation $n+1$ with those in generation $n$ is then given by

$$
\begin{gathered}
I_{n+1}=R_{I Y} Y_{n} \\
Y_{n+1}=R_{Y I} I_{n}
\end{gathered}
$$

Solving this model (Edelstein-Keshet 1988), we find that in the long run

$$
\begin{aligned}
& I_{n}=\left(R_{0}\right)^{n} C_{1} \\
& Y_{n}=\left(R_{0}\right)^{n} C_{2}
\end{aligned}
$$

Where $C_{1}$ and $C_{2}$ are functions of $I_{0}$ and $Y_{0}$, and

$$
R_{0}=\sqrt{R_{I Y} R_{Y I}}
$$

The $R_{I Y}$ and $R_{Y I}$ depend on the details of the infection biology of the system. If we, for example, consider the case shown in figure 5 , we find that (van den Bosch et al. 2006)

$$
R_{0}=\sqrt{\frac{a \frac{\sigma}{h}}{h+\phi} \frac{d P}{\omega+\tau}}
$$

Where $P$ is the total vector density. For more detail on the calculation of $R_{0}$ in virus vector systems, we refer to van den Bosch et al. (2008, 2017). 
considering the role of the vector and its interactions with both the virus and the host plant. We show how modeling can contribute to an understanding of how transmission affects disease dynamics; that vector dispersal, behavior, and host preference arises from the vector interaction with the host; and the fitness effects that arise from virus-vector interactions. Finally, we consider how the complexity of host-virusvector interactions interact with the biotic environment, specifically the tritrophic interactions involving parasitoids and predators, has been modeled.

\section{Abiotic and Biotic Relationships}

A general overview on the use of epidemiological models to forecast plant virus epidemics, based largely on meteorological data, is given by Jones et al. (2010), who identified the steps involved in building a predictive model (Fig. 1). Such an approach can lead to the development of decision support systems and was illustrated using eight case studies in different climatic regions of the world; for example, risk maps for Cucumber mosaic virus (CMV)-lupin in southwest Australia (Fig. 2). Weather-based decision support systems have been combined with extensive survey schemes and coordinated diagnostic methods to model the onset of a range of wheat virus diseases in the Great Plains region of the U.S.A. based on a spatially structured degree-day model for wheat phenology (Burrows et al. 2016). On a more localized scale, most models of environmental impacts have been based on regression or similar empirical statistical approaches, where comprehensive data sets on disease measures, such as incidence, severity, or prevalence, are related to weather variables relating to the different scales appropriate to the disease measures. Similar approaches have been used to predict vector population levels, such as the planthopper Delphacodes kuscheli, vector of Mal de Rio Cuarto virus of maize, in Argentina (Ornaghi et al. 2011). Wind direction and speed can be critical in providing a source of viruliferous vectors as found for Bemisia tabaci in relation to a cassava crop (Colvin et al. 1998). In some cases, prediction of virus disease incidence is made directly from the density of different vector species over time (Raccah et al. 1988).

At larger scales, events such as the El Niño-Southern Oscillation have been associated with years of high or low disease incidence and severity (Chappell et al. 2013; Culbreath and Srinivasan 2011). The potential distributions of virus vectors have been proposed based on Climex mapping (Berzitis et al. 2014; Boag et al. 1997). The species distribution model MaxENT was used to predict the potential impact of Avocado sunblotch viroid in Mexico (VallejoPérez et al. 2017). The applicability of CLIMEX and other species distribution models to species range expansions has been reviewed by Bebber (2015), but with few case studies considered for plant viruses. This approach to modeling the impact of plant virus diseases at regional and global scales is ripe for further development and application.

Many examples can be found in the literature where there is a careful analysis and epidemiological interpretation of factors affecting the vector, virus, and the host as a tripartite interaction. Factors associated with the incidence of Tomato spotted wilt virus (TSWV) on tobacco transmitted by thrips were modeled by considering aspects of thrips and plant biology as functions of weather (Chappell et al. 2013). Disease incidence during the summer months was influenced by weather factors affecting thrips activity during the previous year when a virus reservoir was established in the plants. Spring rainfall and earlier weather then interacted with virus abundance and transmission intensity to affect disease incidence. Similar findings were found with three major virus diseases of maize: Maize streak virus, Maize stripe virus, and Maize mosaic virus (Reynaud et al. 2009). Vector numbers were positively correlated with disease incidence for all three diseases and both were closely associated with temperature variations, less so with rainfall and relative humidity. In early work, Madden et al. (1983) used discriminant analysis to accurately predict the risk of Maize dwarf mosaic virus based on overwintering and early spring environmental conditions. Temperature in the spring months was found to be the main factor associated with the severity of two viruses of melon using multivariate analysis of disease progress curves (Alonso-Prados et al. 2003). Population dynamics of western flower thrips was observed over a 4-year period in Reunion Island using sticky traps and related to climatic data (Boissot et al. 1998). Population variation was associated with temperature variation with marked increases above a threshold. However, because heavy rainfall provided conditions favorable to entomopathogens, this caused population declines before the maximum mean temperature was reached; this is an example of a tritrophic interaction arising through an environmental effect.

In some cases, a more structured approach to modeling the effects of environmental factors has been followed. Epidemics of banana bunchy top disease were modeled using a compartmental susceptibleexposed-infectious-removed (SEIR) model (Fig. 3), together with the population dynamics of the vector Pentalonia nigronervosa as discussed in later sections. The effect of temperature on the model parameters were incorporated into simulations (Raymundo and Pangga 2011). Small increases of 1 to $2^{\circ} \mathrm{C}$ in average monthly temperature over years 1998 to 2007 would have reduced the rates of increase in viruliferous vectors and disease incidence, and delayed disease onset. Such studies illustrate the value of modeling in predicting the impact of climate changes on vectored plant virus diseases (Canto et al. 2009).

\section{Spatiotemporal Analysis of Epidemics}

Spatial analysis of disease patterns, including those of virus infected plants, has a long history. Spatial analysis can highlight the contrast in disease pattern where different vectors are responsible for transmission, e.g., in lettuce with fungal transmission of lettuce big vein disease from soil compared with aphid transmission of Lettuce necrotic yellows virus from external sources (Coutts et al. 2004). Increasingly, it has been appreciated that spatial patterns arise from the temporal progress of disease and that the spatial arrangement of disease foci contribute to subsequent disease spread (Madden et al. 2007, chapter 9). Spatial disease patterns associated with cassava mosaic disease (CMD) in Rwanda and Burundi were analyzed using geostatistical modeling, such as semivariogram analysis (Madden et al. 2007, chapter 9) to interpolate disease intensity between sampling points (Bouwmeester et al. 2012). In plant populations, the threshold for an epidemic (Box 1) to occur may depend on the host distribution in relation to pathogen dispersal, as well as host density (Brown and Bolker 2004). In a model designed to relate the non-linear interactions between plant host availability and begomovirus adaptability to different host species (Jabłońska-Sabuka et al. 2015), spatial diffusion was included over neighboring regions. However, the vector was assumed to be ubiquitous. The spatial pattern of tomato plants infected with Tomato mottle virus and its vector $B$. tabaci was monitored in a large number of experimental plots at different locations over two years (Polston et al. 1996). There were numerous small clusters of symptomatic plants prior to harvest, but no observed relationship between disease aggregation and incidence. However, as demonstrated by Turechek and Madden (1999) and others, for other pathosystems, indices of spatial aggregation are often estimated imprecisely, so it is difficult to show a relationship between incidence and the degree of aggregation that is truly there. Based on the results of fitting the binary power law to aggregation data for a diversity of pathosystems, including some virusplant systems, small-scale aggregation does typically change with changing incidence. Dispersion patterns of the vector were variable for tomato mottle disease epidemics (Polston et al. 1996), but it appeared that immigrant viruliferous vectors were the main driver of epidemics, although frequent insecticide applications were made in these plots.

Gibson (1997), following the earlier study of Gottwald et al. (1996) on the spatiotemporal development of Citrus tristeza virus, developed a stochastic model to characterize the joint infection processes, that is, infections resulting from previously infected individuals in the same epidemic (contagion; secondary infections), and infections arising from inoculum (presumably as viruliferous vectors) arising from other locations such as weeds or other fields of the same crop (primary infections). The model is explicitly spatiotemporal, using spatial patterns of diseased individuals at two or 
more times to determine the rates for the two processes that best produce the patterns at each time. There was no explicit consideration of the vector in the model. The contagion process was explicitly dependent on the distance between healthy and infected individuals. Pethybridge and Madden (2003) used the same model for virus epidemics of hops. For three viruses of hops (Pethybridge and Madden 2003), there was a mixture of local spread due to mechanical transmission by cultural operations and subsequent secondary spread by vectors where these were present. The importance of secondary and primary infection varied for a given virus among locations.

In a wide ranging review of epidemiological models, Gilligan and van den Bosch (2008) discussed how methods for controlling the spread of Rhizomania on sugar beet could be done by matching the scale of control with the spatial and temporal scales of the disease. Spatial as well as temporal spread of virus disease can be affected by cropping practices such as intercropping. When cassava was intercropped with cowpea, temporal rates of increase of CMD were lower than in cassava grown alone, and disease foci were more compact in the intercrop (Fondong et al. 2002). When a disease epidemic is expanding over a large spatial scale, as was found with ACMD in East Africa (Legg and Thresh 2000; Otim-Nape and Thresh 1998), analysis of the disease front has provided valuable information on the role of diseased cuttings and whitefly numbers in expansion and the likely success of control measures (Legg and Ogwal 1998). In this study, there was a clear trend in whitefly numbers, with numbers in northern regions of Uganda significantly greater than in southern regions (Table 1). The expansion of the epidemic front during the course of the study was considered a consequence of the larger vector populations.

The spatial pattern of cacao swollen shoot disease was monitored in Togo, following removal of diseased cacao plots and replanting with less susceptible cacao (Oro et al. 2012). Re-emergence of the disease within the plots occurred in foci in a highly aggregated pattern. Disease progress was highly dependent on the disease incidence in the first year after replanting. This situation was highly predictable from the earlier modeling study of Jeger and Thresh (1993), where the rate of reinfections was reduced by the use of a cordon-sanitaire around the new

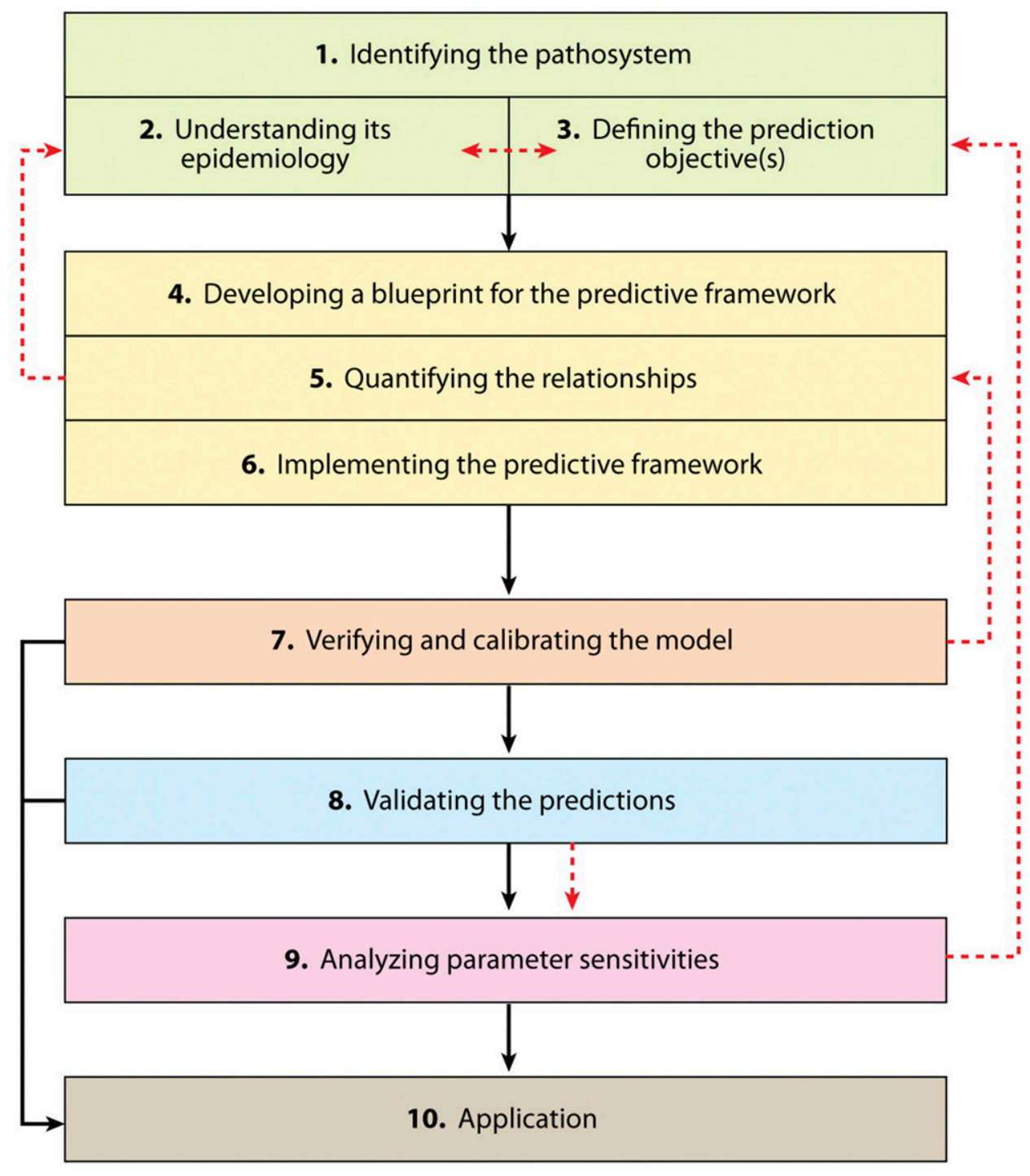

$\longrightarrow$ Chronological steps
$\longrightarrow-->$ Feedback loop (if warranted)

Fig. 1. Steps involved in development of an epidemiological model for plant viruses aimed at prediction of disease dynamics based on meteorological data (Fig. 3 in Jones et al. 2010; reproduced with permission from the Annual Review of Phytopathology, Volume 48 @ 2010 by Annual Reviews, http://www.annualreviews.org). 
plantings. However, replanting with the less-susceptible varieties was found to be crucial in restricting the extent of re-emergence in foci.

\section{Disease Control}

General. In some cases, the modeling of environmental effects on plant virus epidemics has been extended to consideration of disease control measures and their likely effectiveness. Spatial and temporal patterns of virus diseases have often been described for major disease epidemics such as those affecting cassava. A comparison was made of the CMD and cassava brown streak disease (CBSD) pandemics, both vectored by B. tabaci in East Africa (Legg et al. 2011). Different patterns of symptom expression mean that the effectiveness of phytosanitary measures would differ: measures for CMD (foliar symptoms, readily observable before harvest) would be easily implemented but would be limited in effectiveness mainly because of the ease with which disease-free plantings are infected from external sources of inoculum; whereas those for CBSD (restricted to root symptoms, observable only after harvest), although effective, would
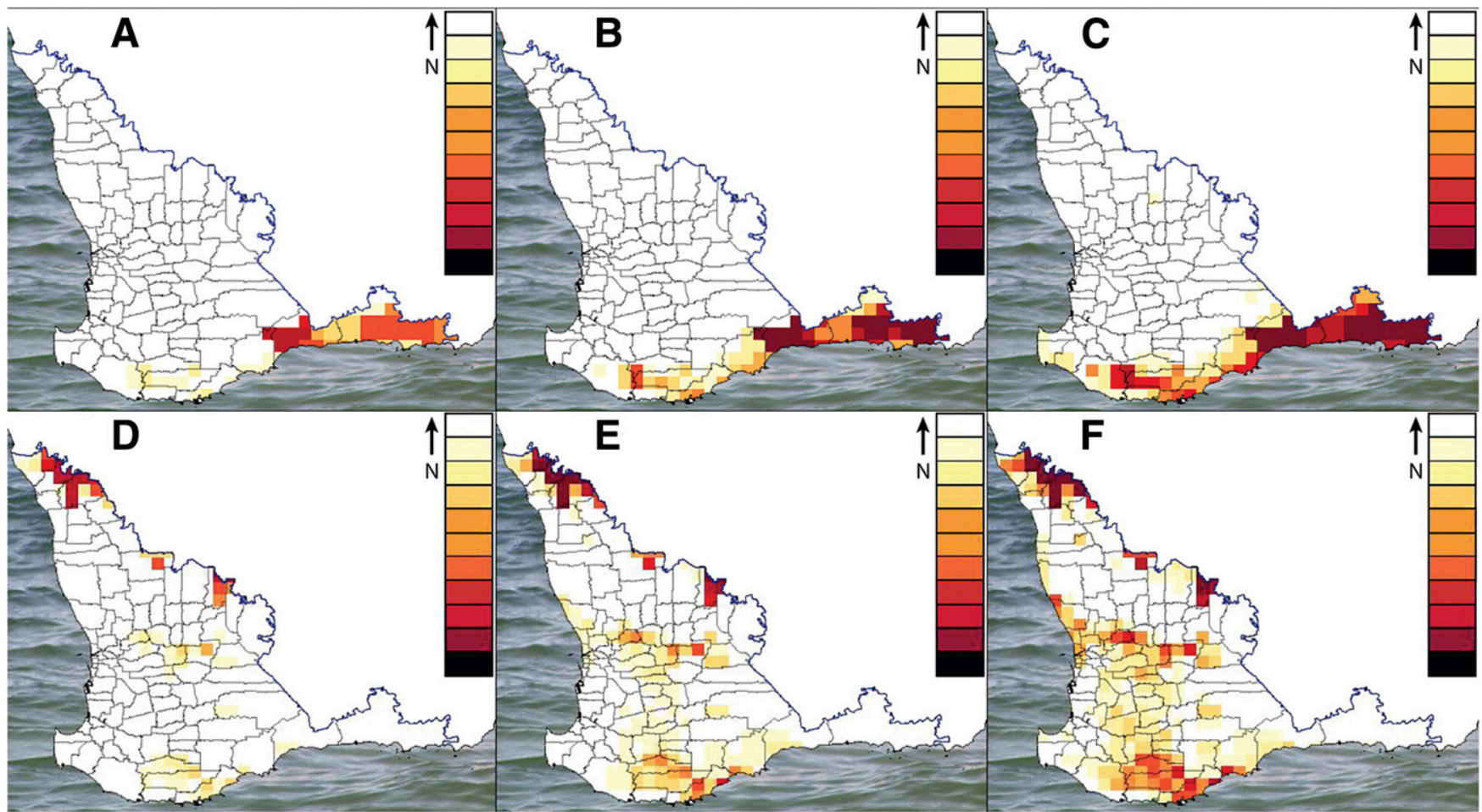

Fig. 2. Risk maps generated for the years 2007 (top row) and 2008 (bottom row) for Cucumber mosaic virus on lupin based on a decision support system: (A, D), (B, E), and (C, F) represent best case (10\% percentile), most likely (50\% percentile), and worst case $(90 \%$ percentile) outcomes respectively. Color coding ranges from $<10 \%$ (white) to $100 \%$ (black) in 10\% intervals (Fig. 5 in Jones et al. 2010; reproduced with permission from the Annual Review of Phytopathology, Volume 48 @ 2010 by Annual Reviews, http://www. annualreviews.org).

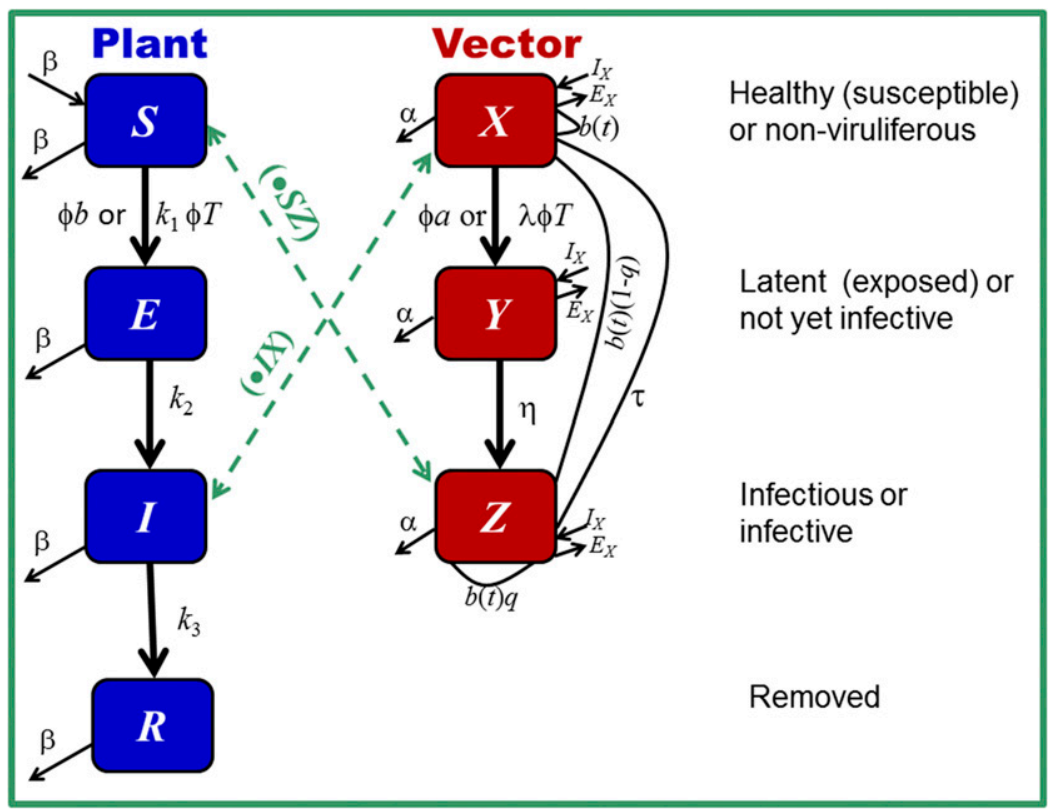

Fig. 3. Schematic of an SEIR model for a plant virus epidemic linked with a vector population model (modified from Fig. 2 in Madden et al. 2000b). Virus acquisition occurs when nonviruliferous vector probe/feed on infectious plants; virus inoculation occurs when viruliferous vectors probe/feed on healthy plants. See Box 2 for a description of the plant categories and Madden et al. (2000b) for a summary specification of the model parameters describing the transitions from the categories. 
be difficult to implement. The temporal relationship between the abundance of the vector with disease incidence highlighted the role of the vector for both diseases and the urgent need to implement control strategies for the vector. A Gompertz model (chapter 4 in Madden et al. 2007) was used to describe epidemics of CMD in West Africa (Fargette et al. 1994), with some $70 \%$ of the variation in disease dynamics related to changes in whitefly numbers together with fluctuations in temperature and radiation. A range of control options has been used against CMD in sub-Saharan Africa with most emphasis on the development and deployment of virus-resistant varieties and little on sanitation measures such as roguing or use of cultural measures such as intercropping (Thresh and Cooter 2005). Large scale screening of cassava for resistance to $B$. tabaci has emphasized the levels of whitefly infestation and preferential whitefly visitation at different locations in Nigeria (Ariyo et al. 2005).

Identification of latently diseased plants is a key issue for effective control. As noted by Rimbaud et al. (2015a), there is often confusion between what is meant by the incubation and latent periods, and any lack of synchrony between the two periods can affect epidemic dynamics and disease control strategies. This may be critical for vector-borne virus diseases, although for Sharka disease of peach, caused by Plum pox virus (PPV), the periods were effectively synchronous. These authors also reviewed worldwide experiences in Sharka control using virus-free planting material, varietal improvement, surveillance and removal of diseased trees, and statistical modeling to obtain insight into management strategies (Rimbaud et al. 2015 b); insights that may be of general relevance for virus disease in perennial crops.

Modeling of control interventions using more structured epidemiological models and their short-term consequences have been reviewed by Jeger et al. (2004) and from an evolutionary perspective by van den Bosch et al. (2007), where the longer term impacts of host resistance, cultural practices, and in vitro propagation methods were evaluated (Fig. 4). In vitro propagation, use of diagnostics, and some breeding methods carry a risk of control breakdown due to selection of virus strains that build up a high titer within plants. Roguing as a cultural control measure in vegetatively propagated crops has a low risk of failure due to reducing titer build up and increasing healthy

\section{BOX 2 \\ The SEIR compartmental model for disease dynamics}

In an SEIR model, the host population is considered as being composed of compartments. The components are non-overlapping host categories according to their infection status of susceptible (and healthy), exposed (infected but with the vector not yet able to acquire the virus), infectious (infected, with possible acquisition by the vector), and removed (postinfectious; the vector can no longer acquire the virus). The SEIR model can be represented as a transition model in which the host population moves from one host category to the next:

$$
\mathrm{S} \rightarrow \mathrm{E} \rightarrow \mathrm{I} \rightarrow \mathrm{R}
$$

The rate of change in in each category is given by a differential equation (although a discrete time formulation is also possible). The "flows" from each category are given by rate parameters usually assumed to be exponentially distributed, an assumption that can be questioned. Other parameters can include birth and death parameters affecting some or all of the categories, and rates of immigration and emigration. The basic model can be simplified by assuming that for some viruses, the period that an infected plant remains in the exposed category can be very short and hence the model reduces to three differential equation; or that there is no removed category, with the infectious plant "losing" the virus and returning to being again susceptible to further infection.

The first SEIR model proposed for plant virus diseases was Chan and Jeger (1994), and was used to derive an $R_{0}$ expression. This was then used to evaluate the likely success of roguing as a control option for four virus diseases of perennial fruit trees. There was no consideration of the vector involved in transmission of the viruses. Subsequently, we expanded the basic SEIR model to include a compartmental model for the vector population, where vector can be nonviruliferous (not carrying the virus, but able to acquire virus from an infectious plant), noninoculative (carrying the virus but not yet able to inoculate a healthy plant), or viruliferous and inoculative (carrying the virus and able to inoculate a healthy plant). This is the representation shown in Figure 3. In Jeger et al. (1998) and Madden et al. (2000b), the symbols used for the successive host plant categories were $\mathrm{H}, \mathrm{L}, \mathrm{S}$, and R, but the underlying model remains the same.

A problem with compartmental models, including SEIR models, is estimating parameters from observational data. There are some examples in the plant virus literature. Madden et al. (1987a) estimated the parameter values for the Lotka-Volterra competition equations from field data on two tobacco viruses. A worked example was included in Madden et al. (2007; section 6.6.2) for field data on Tobacco etch virus using the MODEL procedure of SAS but including separately assumed values for some of the parameters. Simultaneous estimation of all parameters in a compartmental model is problematic, especially where the number of data points is limited and as the numbers of model equations increases. Advances in statistical and computational techniques should help to meet this challenge in the future.

Table 1. Mean adult whitefly counts on the undersides of the top five leaves of 30 cassava plants in 10 farmers' plantings within a 1-km radius of localities at successive distances north from Kampala (central transect) and Tororo (eastern transect); data taken from Table 2 in Legg and Ogwal (1998). Counts followed by the same letter in a column do not differ significantly at $P=0.05$ (Mann-Whitney statistic).

\begin{tabular}{lccc}
\hline \multicolumn{2}{c}{ Central transect } & \multicolumn{2}{c}{ Eastern transect } \\
\cline { 1 - 3 } Distance from Kampala & Mean whitefly numbers & & Distance from Tororo \\
\hline 0 & $0.8 \mathrm{a}$ & 0 & $0.4 \mathrm{ab}$ \\
20 & $0.6 \mathrm{a}$ & 10 & $0.3 \mathrm{a}$ \\
40 & $0.6 \mathrm{a}$ & 20 & $0.3 \mathrm{a}$ \\
60 & $1.5 \mathrm{ab}$ & 30 & $0.4 \mathrm{a}$ \\
80 & $2.5 \mathrm{c}$ & 40 & $0.7 \mathrm{c}$ \\
100 & $3.7 \mathrm{c}$ & 50 & $0.5 \mathrm{bc}$ \\
120 & $1.6 \mathrm{bc}$ & 60 & $0.4 \mathrm{abc}$ \\
140 & $2.2 \mathrm{bc}$ & 70 & $1.2 \mathrm{~d}$ \\
160 & $2.0 \mathrm{bc}$ & 80 & $0.9 \mathrm{~cd}$ \\
180 & $1.4 \mathrm{bc}$ & 90 & $1.1 \mathrm{~d}$ \\
\hline
\end{tabular}


plant density. Methods of cultural control have also been modeled and evaluated in relation to economic threshold theory (Zhao and Xiao 2015).

Host resistance. Host resistance has been the preferred approach to virus disease control whenever resistant genotypes are available. Knowledge of natural virus resistance genes was reviewed by Maule et al. (2007). Models have been used in a range of contexts to evaluate field evaluation, analyze resistance deployment strategies, and predict the likely durability of resistance given the mechanisms involved (van den Bosch et al. 2008) (Fig. 5). Resistance that reduces virus acquisition by the vector and reduced inoculation of the host plant do not select for virus evolution to a higher multiplication rate within the host plant. Resistance that reduces within-plant virus titer or reduces symptom development does select for a higher multiplication rate.

On-farm field trials in different agro-ecological zones are standard practice in cultivar evaluation. Assessment techniques using the area under disease progress curve (AUDPC) combined with vector population numbers gave information on the relationship between cultivar resistance and the relationship between CMD incidence and whitefly numbers (Otim-Nape et al. 1998). A simulation model was used to investigate the interaction of host resistance and phytosanitation (cutting selection) in CMD (Fargette and Vié 1995). When resistance was accompanied by the phenomenon of reversion (healthy cuttings derived from diseased plants), equilibrium was reached in which new infections by vectors were balanced by "escapes" through reversion or cutting selection (Fig. 6). Physical and biochemical traits can reduce the landing, settling, and probing of insect vector of plant viruses, as found for B. tabaci, the vector of Tomato yellow leaf curl virus (TYLCV) (Rodríguez-López et al. 2011). The virus is restricted to the phloem and transmitted in a persistent manner by the whitefly, so the reduced ability to reach the phloem may prevent spread of the disease within the crop. Resistance in soybean to feeding by the leaf beetle vector Cerotoma trifurcata was not sufficient to reduce the incidence and spread of Bean pod mottle virus (Redinbaugh et al. 2010). Viruses are known to adapt to qualitative monogenic ( $\mathrm{R}$ gene) resistances, but the evidence for adaptation to quantitative polygenic resistance has been less well documented (Montarry et al. 2012). In a study on Potato virus $Y$ (PVY) and two pepper genotypes, experimental evolution showed that quantitative resistance breakdown can occur and is not necessarily durable. The case has been made for pyramiding viral resistance genes rather than relying on single resistance genes where there is frequent recombination, as in begomoviruses (Prasanna et al. 2015). There may also be fitness costs associated with resistance; for example, a tobacco cultivar resistant to PVY showed increased sensitivity to elevated ozone compared with a susceptible cultivar (Ye et al. 2012). On the other hand, in the same system, plants grown under elevated $\mathrm{CO}_{2}$ appeared to reduce virus resistance costs (Ye et al. 2010). The modeling of durable resistance and fitness costs is taken up in later sections of this review.

Tolerance to plant viruses is often referred to in plant breeding and crop improvement programs, but often without adequate definition or distinction made from resistance. According to Buddenhagen (1983), a plant is tolerant "to some degree" if it suffers less damage (e.g., symptoms) than other plants when infected by a systemic pathogen such as a virus. More recently, Seal et al. (2006) noted that many "resistant" plant cultivars grown are tolerant in the sense that they express less conspicuous symptoms but have the same virus content as "sensitive" cultivars. Thus the dangers in deploying tolerant cultivars in this sense is that high yield losses may result if tolerance breaks down and these cultivars provide a virus reservoir. Epidemiological models incorporating tolerance to viruses as a host plant category have not been proposed, although on evolutionary time scales, tolerance may lead to selection of virus strains that lead to greater virus accumulation in the host (van den Bosch et al. 2006). For natural plant communities, tolerance has been interpreted as the plant accommodating a virus without affecting plant fitness (Alexander et al. 2017; Cronin et al. 2014), where fitness is assessed using a range of lifehistory modeling techniques.

Roguing. Roguing as a method of cultural control, sometimes combined with replanting of healthy material, has often been advocated in field practices and temporal models have been proposed to evaluate whether eradication is feasible (Chan and Jeger 1994). However, as noted above, spatial aspects may be an important element in evaluating the practicality and effectiveness of roguing at different levels. In general, much of the modeling work has been theoretical in an attempt to determine what needs to be done to achieve a given level of disease control; this is similar to the theoretical work in human epidemiology related to the percent of the susceptible population that must be immunized in order to prevent an epidemic. Advanced mathematical modeling of generic roguing/replanting strategies for plant diseases has been done by Luo et al. (2015) and van den Bosch and de Roos (1996). Gao et al. (2015) used a model to evaluate the effects of control measures when roguing

Epidemiology of virus diseases in crops propagated by cuttings from previous crop or by in vitro methods.

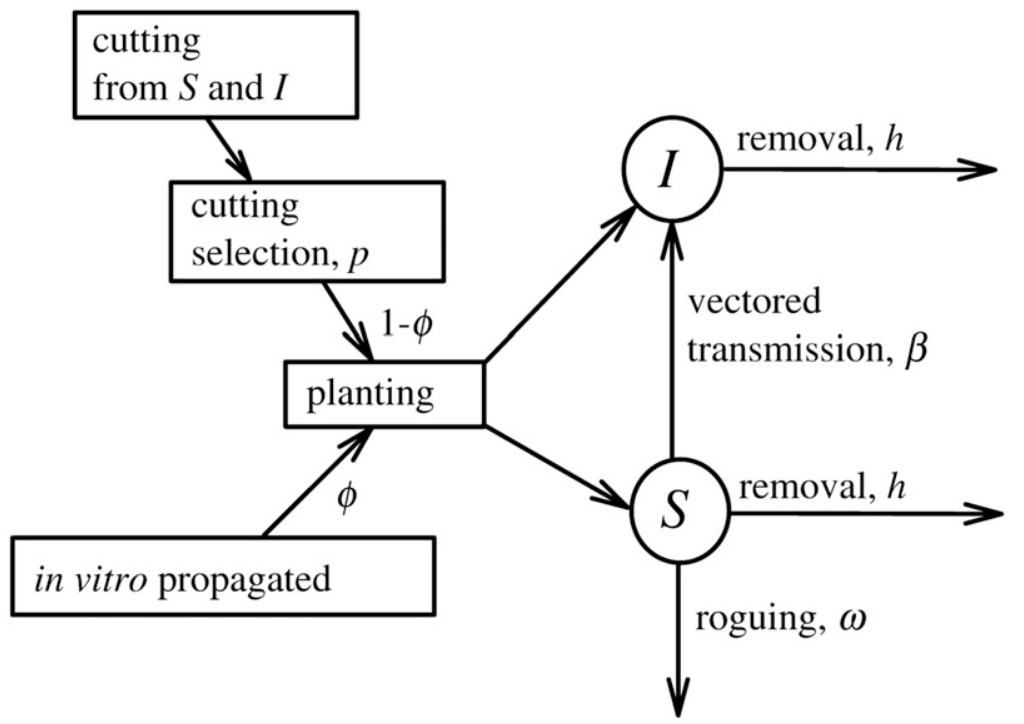

Fig. 4. Schematic showing the model structure for virus disease dynamics in vegetatively propagated crops, either though cuttings or through in vitro methods (Fig. 1 in van den Bosch et al. 2007, copyright The Royal Society). Variables S and I represent healthy and infectious plants, respectively; see van den Bosch et al. (2007) for specification of model parameters. 
and replanting were practiced. With high infection rates, it may not be possible to eradicate the disease, and increasing replanting rates from relatively small values may be counterproductive in control (Fig. 7). These authors also showed that previous models that modeled roguing as a continuous activity may overestimate the infection risk compared with the more realistic intermittent roguing. This applies to the estimates used for continuous roguing in Jeger et al. (2004) which, as pointed out by Cunniffe et al. (2014), were overestimated. Spatially explicit simulation models were used to evaluate different management approaches to roguing and replacement as a means of disease suppression (Sisterson and Stenger 2013). Efficient replacement of infected plants and a high level of compliance among

\section{Host resistance and the evolutionary response of plant viruses}

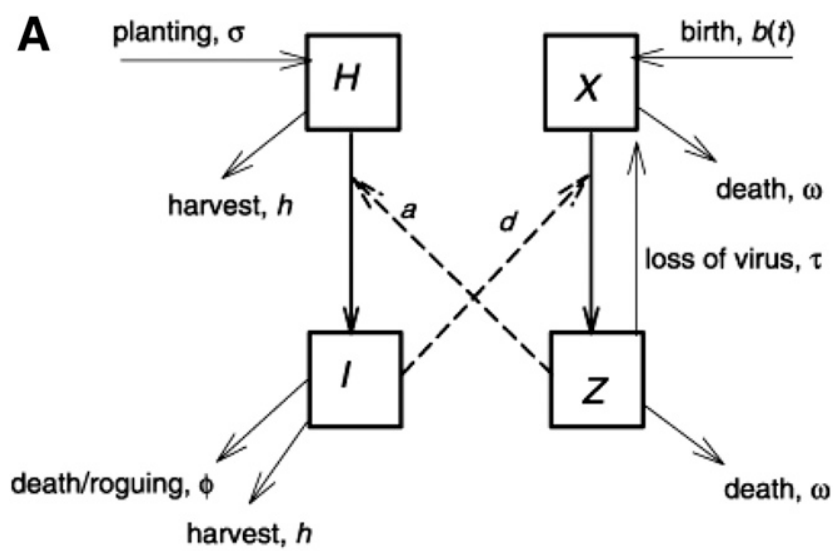

B

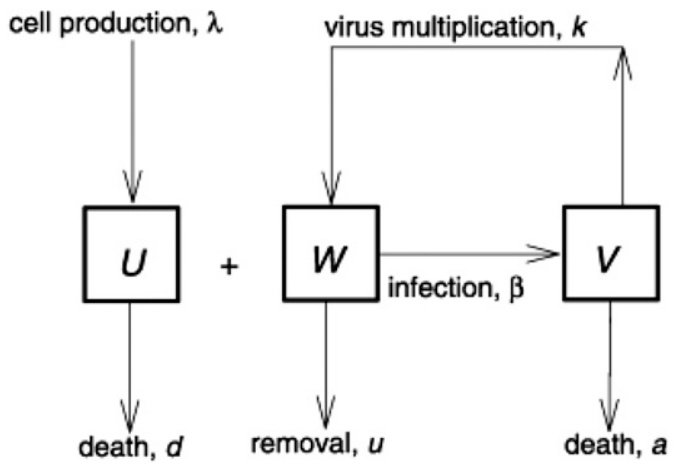

Fig. 5. Schematic showing the hierarchical model structure for virus disease dynamics with $(\mathbf{A})$ between-plant vector transmission and (B) within-plant virus multiplication (Fig. 1 in van den Bosch et al. 2006, copyright Rothamsted Research). Variables $\mathrm{H}$ and I represent healthy and infectious plants respectively, $\mathrm{U}$ and $\mathrm{V}$ represent uninfected and infected plant cells respectively, and $W$ the density of virions within plant cells; see van den Bosch et al. (2006) for specification of model parameters. farmers in a crop-growing region were found necessary to reduce both disease spread and ultimately the need for replacements. Results in terms of yield depended on whether infected plants produced usable yields.

The potential of roguing in annual crops has rarely been considered. A model of rice tungro virus disease was developed, by making assumptions of virus transmission rates, vector population dynamics, and the probability of dispersal (Holt and Chancellor 1996). With high or medium disease incidence, roguing was relatively ineffective. With low disease incidence, roguing was inconsequential. The reasons the authors give for the apparent failure of roguing was that with realistic times to symptom development, there is a significant period during which infected rice plants can act as virus sources prior to their removal, and hence secondary spread by vectors is not effectively constrained by roguing.

There are also examples of where modeling has contributed for specific plant virus diseases. An economic analysis of control strategies for grapevine leaf roll disease based on roguing and replanting was made by Atallah et al. (2015). A spatial diffusion model was linked with a bio-economic model to evaluate spatial and nonspatial control measures and ranked according to expected net economic values. Targeted spatial measures based on roguing of symptomatic vines and replanting, coupled with testing nearest neighbors and then roguing and replanting if the test was positive, were better than nonspatial measures based only on symptomatic vines, and increased the expected net present value by 18 to $19 \%$ compared with the strategy no disease control. Factors affecting the spread of an aggressive strain of PPV in peach orchards in southern France were analyzed where orchards were subjected to regular inspection and removal of symptomatic trees (Dallot et al. 2004). An extensive list of variables was included in a model to determine those most important in determining the risk of

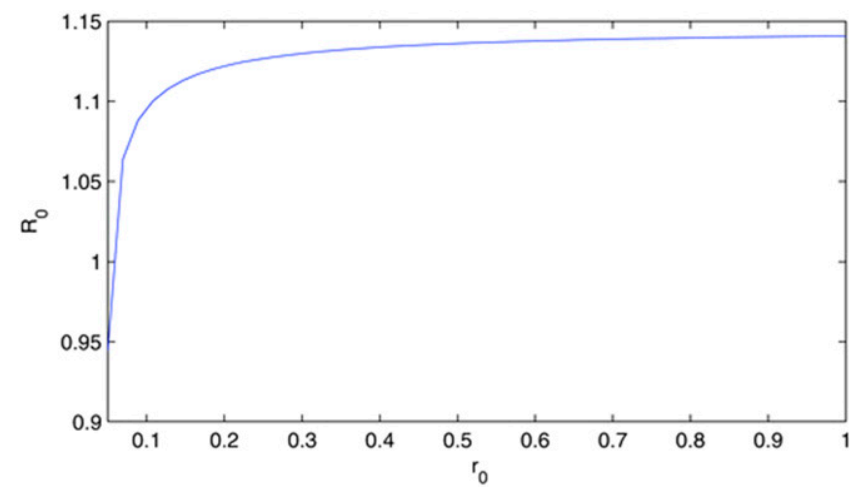

Fig. 7. Graph showing the sensitivity of the basic reproduction number $R_{0}$ to the average replanting rate $r_{0}$, where the average is calculated from a trigonometric parameter function for replanting rate representing a periodic environment (Fig. 6 in Gao et al. 2015, with permission from John Wiley and Sons).
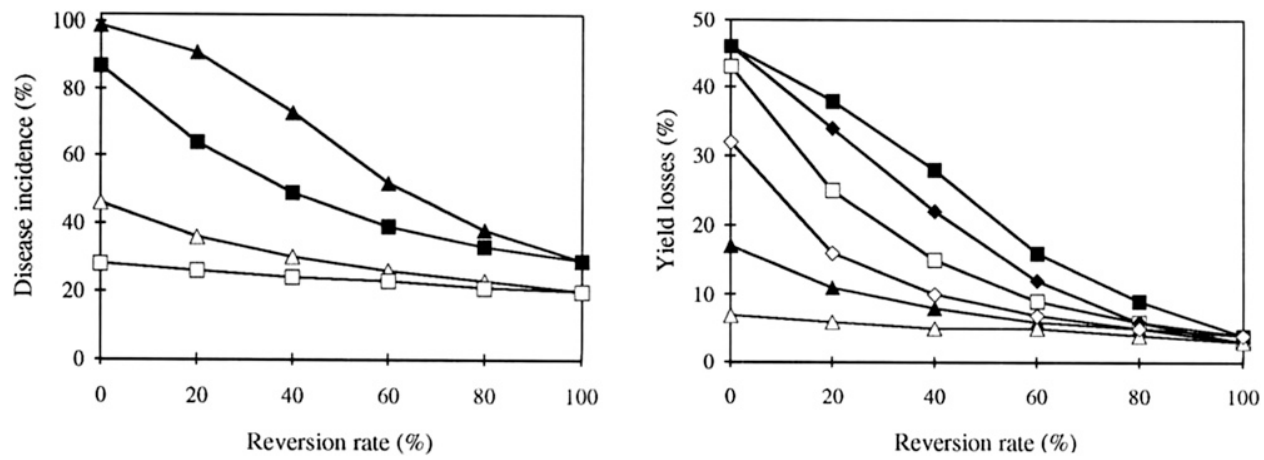

Fig. 6. Relationship between (left) final disease incidence after 10 crop cycles and (right) yield losses, in relation to reversion rate (\% healthy cuttings derived from infected plants) in a semidiscrete-time model of African cassava mosaic disease dynamics (Figs. 7 and 8 in Fargette and Vie 1995, republished with permission of the Americal Phytopathological Society). Symbols represent different cutting selection ratios (healthy/infected) and rates of secondary spread; see Fargette and Vié (1995) for specification of model parameters and values. 
a tree becoming infected during the period of spread. Plum pox infections originated from external virus sources, the transition from latent infections to infectious trees, as well as from lack of detection of infectious trees and/or delayed roguing. Annual removal of symptomatic trees slowed the rate of increase of the disease but did not achieve complete eradication. Smith et al. (1998) linked a temporal model of disease increase with disease gradients reflecting the reduction of Banana bunchy top disease with distance from the periphery of a banana plantation (reflecting the importance of external virus inoculum) to investigate roguing and replanting strategies. Variable roguing rates based on spatial considerations gave small improvements over nonspatial constant rates, but too much emphasis on the periphery could lead to a major increase of disease in the plantation (Fig. 8).

Production systems. Plant production systems come in many forms that can affect disease progress. These include the crop cycle, whether annual or perennial; linked multiplication and production sites; protected versus field production; variety mixtures, intercropping, and multiple cropping; planting date; and field separation. Mathematical models have been developed as a means of analyzing key factors relating to plant virus epidemics, despite questioning (Döring 2011) whether models will ever sufficiently capture the complexity of virus-vector-host-environment-production system interactions to enable the singling out of key factors.

The temporal and spatial scales of plant virus epidemics in annual and perennial cropping systems differ substantially. For annual production cycles, the presence of relatively few vectors at the beginning of the cycle decreases subsequent disease spread. Viteri and Gordillo (2009), using a differential equation model for nonpersistent virus transmission, showed the importance of these early events but also gave approximations to disease incidences in subsequent plantings.

Often, especially in tropical developing countries, farmers may be faced with whether to use diseased or disease-free planting material from the previous year's harvest. Such a situation was modeled by Holt et al. (1997) for Cassava mosaic virus, based on the assumption that the choice of material was based on the relative frequency of healthy cuttings. The supply of disease-free planting material from a multiplication site to growers as a means of controlling cassava brown streak disease in East Africa was investigated using mathematical modeling (McQuaid et al. 2016). As a result of the modeling, it was recommended that multiplication sites be established only where disease pressure and vector populations are low but that varieties showing strong foliar symptoms are to be preferred to allow for effective roguing. For a linked plantation-nursery system, where diseased trees in the plantation are replaced by healthy plants from the nursery, the long term effects on disease in the plantation were examined by Gani and Stals $(2004,2005)$ using a stochastic (Markov
Chain) approach. A similar example was used by van den Bosch et al. (2008) to illustrate the challenges in deriving an expression for the basic reproduction number, $R_{0}$, for vectored plant diseases in a linked nursery-plantation production system. Recently, models including true seed (Hilker et al. 2017) and planting material (Thomas Sharma et al. 2017) transmission have determined the long-term consequences for plant virus epidemics.

Protected cultivation systems offer many advantages over field systems for providing physical protection of crops against virus vectors. Monomolecular and Gompertz functions (chapter 4 in Madden et al. 2007) were used to describe the development of Tomato chlorosis virus and TYLCV in greenhouse and net houses of varying quality (Velasco et al. 2008). Control of both diseases was only achieved under high quality coverings. Insect-screening barriers were constructed to prevent the entry of $B$. tabaci into tomato plots (Holt et al. 2008). A mathematical model was fitted to data on symptoms of TYLCV and Potato yellow mosaic virus in the treated (with barriers) and control (without) plots. It was estimated that the barriers reduced vector entry by about 12 -fold, but that those that entered were retained to a greater extent than in those without barriers. In some circumstances, after an initial delay, there can be more rapid increase within barriers once the vector population is established.

The effectiveness of mixtures of resistant and susceptible cultivars in production systems across different scales was emphasized by Fabre et al. (2012). Virus epidemics were modeled in a landscape consisting of a mosaic of susceptible and resistant fields where there was seasonality and a year-round reservoir of virus. Results showed that the optimal strategy for landscape deployment of resistance include both mixtures of susceptible and resistant cultivars and a single pure cultivar strategy depending on resistance characteristics, epidemic incidence, and landscape connectivity. Intercropping can reduce the temporal rate of progress of a virus disease and affect its spatial pattern of development (Fondong et al. 2002). Intercropping tomato with several other crop species was investigated in an attempt to reduce or delay outbreaks of Tomato leaf curl virus (TLCV) (Fargalla et al. 2011). The lowest percentage of TYLCV was found on intercropping with cucumber where the highest densities of adult stages were found.

\section{Plant Population and Community Dynamics}

Natural plant populations and communities offer a higher level of complexity than crop populations. The value of structured population models of plants and the environmental drivers (biotic and abiotic) that drive plant demography has been reviewed (Ehrlén et al. 2016), including reciprocal feedback between plants and their biotic drivers. There is often a dynamic interface between agricultural landscapes and natural or relatively unmanaged ones. At this interface,
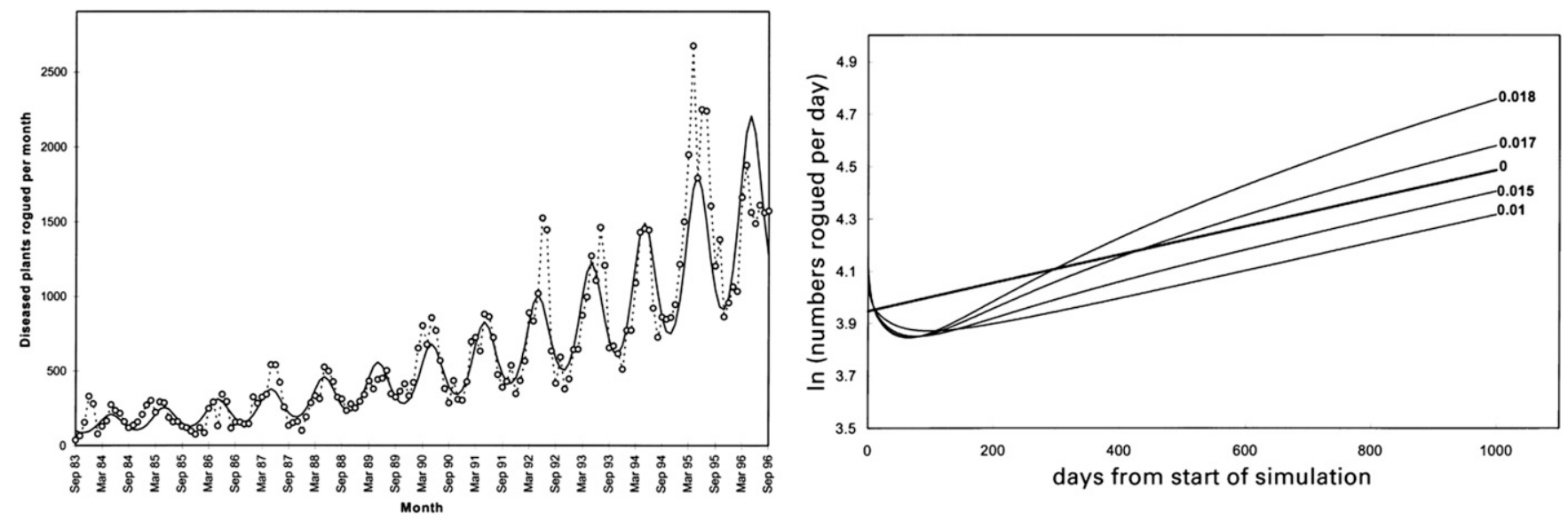

Fig. 8. (Left) Observed (circles) and fitted numbers (trigonometric regression) of Banana bunchy top diseased plants rogued per month over the years 1983 to 1996 (Fig. 2 in Smith et al. 1998); and (right) effect of roguing regimes with different gradients of emphasis on outer versus inner regions of plantation on the slope of the disease progress curve (Fig. 7 in Smith et al. 1998, copyright BSPP with permission from John Wiley and Sons). With heavier emphasis on the outer regions (0.017 and 0.018$)$, although there was an initial decrease in disease dynamics compared with no emphasis (0), there was a subsequent and marked increase in the rate as secondary spread began to dominate in the plantation. See Smith et al. (1998) for specification of the underlying discrete-time SEIR-type model and its spatial representation. 
crop relics, weed plants, endemic plant communities, and sometimes invasive exotic plants may be present, providing opportunities for virus transmission by vectors, sometimes in novel combinations (Alexander et al. 2014). Quantitative evaluation of such interaction can provide valuable insights into crop performance and disease ecology. Plasticity of life history traits can be noted in wild plant populations. Tolerance to virus infection and the direct (due to infection) and indirect (due to changes in competitive ability) fitness costs were studied in the natural Arabidopsis thaliana/CMV system (Pagán et al. 2008, 2009). The combined effects of host density and virus infection modulate the competitive ability of the host plant and need to be taken into account when considering coevolutionary processes and incorporated into modeling approaches.

Extensive research has been carried out on Barley yellow dwarf virus (BYDV) and Cereal yellow dwarf virus (CYDV) affecting native grasslands along the Pacific Northwest coast of the U.S.A. (Borer et al. 2009; Power et al. 2011). Evidence has suggested that infection by viruses has facilitated the invasion of European annual grasses. Overall, it was concluded that patterns of virus incidence were strongly influenced by the interaction of both biotic and abiotic factors, as in the interaction found with BYDV in wheat in southwestern Australia (Thackray et al. 2009). The B/CYDV system has been modeled (Moore et al. 2011) to determine the extent to which the system can persist locally or in a patch framework where there are interactions between native perennials and annual invaders. In some cases, the viruses may facilitate the invasion of the non-native species. Under new encounter scenarios, indigenous viruses from isolated indigenous plant populations can spread to an introduced crop species (Webster et al. 2007) and such systems may also be amenable to epidemiological modeling.

\section{Evolutionary Epidemiology}

Linking a population dynamic approach with an evolutionary perspective has been seen as an important development in virus epidemiology over the last decade. It has provided new insights into the factors governing virus emergence, the evolution of virulence, and the scaling up from within-plant processes and interactions to virus epidemics. Modeling, in conjunction with experimental studies, can serve to link epidemiological/ecological with evolutionary time scales, although the challenges are many.

Virus emergence. Novel virus-vector-crop-environment interactions often arise from major agricultural innovations and may lead to emergence of new viruses or virulent strains (Fargette et al. 2006). Major amplifications of epidemics associated with novel virus recombinants and vector genotype clusters have occurred as found with CMD in East Africa (Legg and Thresh 2000; Legg et al. 2002, 2011). The use of TYLCV resistance in tomato crops may have contributed to its emergence in mixed populations of TYLCV-associated viruses (García-Andrés et al. 2009). Crop introductions and founder virus populations may be important in subsequent epidemic spread. Impatiens necrotic spot virus causes major damage to glasshousegrown ornamental plant in Japan. Genetic analyses of isolates were made to elucidate how the virus invaded and spread within a local area (Nekoduka et al. 2015). Phylogenetic analyses showed that isolates clustered with isolates from elsewhere in Japan and other countries, but that host species did not influence genetic structure. It was concluded that founder populations were introduced individually from other regions and then spread locally.

Virus emergence starts with the transmission of genetic variants from a preexisting reservoir, a stochastic process. The subsequent fate of these variants depends upon fitness on the new host, adaptation to that host and vector, and the efficiency of subsequent spread in the host population (Elena et al. 2014). Virus emergence is conditional on a reservoir of the pathogen being available to invade a crop population. The hypothesis is that short-lived hosts, because of less investment in costly defenses, will act as effective reservoirs, maintaining larger vector populations that serve as a source of inoculum for longer lived plants (Hily et al. 2014). Using a model, it was concluded that within-species genetic diversity for plant lifespan and defenses would lead to a polymorphism for virus reservoir potential and hence the dynamics of virus emergence. A major element in considering the evolution and emergence of plant viruses has been hypothesized fitness trade-offs on new hosts or host genotypes. GarcíaArenal and Fraile (2013) reviewed the evidence for predictions based on this hypothesis. Evidence can be found for across species tradeoffs involving host adaptation, but the evidence for across host tradeoffs is stronger; for example, overcoming dominant resistance is linked to severe fitness costs in virus genotypes. The ("scanty") evidence supporting plant-virus coevolution is reviewed by Fraile and García-Arenal (2010).

Virulence evolution. The evolution of virulence and pathogenicity is another topic that has raised the interest of modelers (Sacristán and García-Arenal 2008). Quantitative evaluation of the evolutionary mechanisms for plant viruses appear similar to those measured for animal viruses (Desbiez et al. 2011). Information on the genetic diversity and evolutionary history of plant viruses is critical for understanding their epidemiology (Kaye et al. 2011) and for anticipating future evolutionary change, including virulence. High rates of mutation contribute to the rapid evolution of geminivirus genomes in plants, but reversion and second site mutations can also occur (ArguelloAstorga et al. 2007). Virulence evolution of a generalist plant virus that infects multiple hosts was modeled for CMV (Betancourt et al. 2013). Two hosts were considered in which CMV genotypes differed for within-host multiplication and virulence. The virus moved from plant to plant and mixed infections were allowed. An asymmetry in virulence evolution was found dependent on the host suitability; evolutionary trajectories differed at low and high vector densities. There was no evidence for trade-offs between CMV life-history traits.

The relationship between vertical transmission and horizontal transmission in relation to virulence has been investigated theoretically (Hamelin et al. 2016; references in Pagán et al. 2014), but experimental evidence has rarely been sought for plant viruses. Pagán et al. (2014) quantified seed transmission of CMV in A. thaliana over five serial passages. Serial passaging led to greater adaptation to seed transmission, with increased rates but reduced virus accumulation and virulence. Horizontal transmission did not significantly affect virus accumulation or virulence. There was also host adaptation during seed transmission that was traded off against reduced resistance to non-evolved viruses. Mutualistic as opposed to parasitic plant-virus symbioses are proposed by Bao and Roossinck (2013) based on host reproduction rate and environmental capacity. Mutualism described by modified Lotka-Volterra equations may reach stable equilibria and is supported by observed examples. At this point in time, there is no equivalent to the transmission-virulence terminology and debate when mutualistic rather than parasitic associations are considered (Hamelin et al. 2017; Hily et al. 2016).

Within-plant dynamics. A few attempts have been made to model virus dynamics and interactions within plants and how these affect subsequent transmission by vectors and hence dynamics of disease (Jeger et al. 2011b; van den Bosch et al. 2006). Much evidence has now been obtained on plant dynamics and localization of viruses within host cells and how virus titer in plants is related to virus acquisition by vectors, e.g., for Southern rice black-streaked dwarf virus (SRBSDV) and the planthopper vector Sogatella furcifera (Matsukura et al. 2013).

Interactions between viruses within host plants have been modeled for synergism (Zhang et al. 2001), cross protection (Zhang and Holt 2001), and the role of helper-dependent virus complexes in transmission (Zhang et al. 2000a). The parameters used to describe the withinhost interactions were implicit rather than explicitly representing their dynamics. One of the few models that integrates within- and between-host dynamics as a means of identifying the key determinants of resistance durability was developed by Fabre et al. (2009). Global sensitivity analysis allowed the ranking of genetic and epidemiological parameters of the model according to the mean and variance of the estimated risk of resistance breakdown.

\section{The Vector Component}

Transmission. Transmission is the key epidemiological process that links all three components of the tripartite virus-vector-plant 
interaction. Even though seed transmission is well known for many plant viruses and even for some unsuspected plant-virus combinations (Kim et al. 2015), virus diseases that are both seed- and vectortransmitted are often the most significant virus diseases of a crop (Moreno and Fereres 2012). In comparison with vector transmission, little is known about the transmission efficiency for those viruses where contact transmission is the norm, such as Tobacco mosaic virus (Sacristán et al. 2011). Unlike vector transmission, no positive correlation was found between virus titer and transmission rate within the range of experimental conditions tested.

Models based on the transmission characteristics in virus-vectorplant systems encapsulate many of the essential features of plant virus epidemics (Jeger et al. 1998, 2009, 2011a, 2015; Madden et al. 2000b) shown schematically in Figure 3. In the earlier of these publications (Jeger et al. 1998; Madden et al. 2000b), a main objective was to compare the effect of the different types on transmission (nonpersistent, semipersistent, and persistent) on disease dynamics and more comparison of transmission type is needed when considering the vector component. In all such models, there is a trade-off between complexity in terms of the tripartite interactions that occur in the system and the need for simplicity for model tractability and analysis. Many epidemiological models assume constant birth and death rates for vectors irrespective of whether they are viruliferous or nonviruliferous. A range of model assumptions on birth and death rates was made by Sisterson (2009), who found important effects on the vector population affecting disease incidence. Where there are separated geographical distributions of a virus vector, the differences in their vectoring ability (i.e., transmission efficiency) may account for the lack of disease in one location versus another. However, this was found not to be the case for the planthopper Perkinsiella saccharici$d a e$, the vector of the virus-induced disease Fiji leaf gall in Australia (Ridley et al. 2006), with the implication that quarantine and/or physical barriers were effective.

Multiple vector species may transmit viruses within a crop, although inoculation efficiency by a single vector may be low as found for Zucchini yellow mosaic virus (Katis et al. 2006). Members of the genus Torradovirus can be transmitted by several whitefly species, which themselves may transmit more than one torradovirus (Verbeek et al. 2014). Models have been proposed that deal with multiple vectors and the combined effect of their transmission (Marcus and Raccah 1986). Multiple vector species as well as pooled vector density were modeled by Madden et al. (1990). The basic reproductive number for systems in which multiple vectors transmit a single virus species is a simple extension of the case where there is a single vector species, although competition between vector species can complicate the derivation (van den Bosch and Jeger 2017).

Vector dispersal, behavior, and host preference. It has long been recognized that plant virus disease epidemics are directly affected by factors related to the vector, e.g., their population dynamics, dispersal, and transmission, as shown schematically in Figure 3 together with the factors that can affect these processes (host nutrition, host infection status, other organisms, etc.). There has also been much recent recognition that the vector-virus interaction can lead to indirect induced effects: changes in vector dispersal, probing and feeding behavior on plants, and their response to host status, whether healthy or infected.

Direct population effects. In terms of direct effects, the spread of Beet mosaic virus in sugar beet fields may be explained on the basis of the initial infection date and vector abundance following migration, as shown by regression analysis and a mechanistic simulation model (Dusi et al. 2000). Many insect vectors of plant virus diseases make only short visits to the crops where the disease is of economic importance. In these cases, the rate of immigration from alternative hosts, e.g., weed species surrounding crops, are major determinants of the rate of disease progress. These features were incorporated into a model of TLCV (Holt et al. 1999). Varietal resistance could be an important component in managing the disease, but once infected, a plant had little impact on subsequent disease incidence in the crop. However, even a very low modeled rate of immigration could cause almost total infection. Insecticides causing insect mortality were only effective when vector numbers were low. Continued migration of viruliferous vectors made disease incidence largely insensitive to vector mortality within the tomato crop. More generally, immigration and emigration processes can be incorporated into theoretical models (Jeger et al. 1998; Madden et al. 2000b; Marcus and Raccah 1986). However, if vector immigration is limited to the primary infection events rather than being continuous, then the added complexity of including immigration may not be necessary.

The movement of the aphid vectors of plant viruses affects both temporal and spatial patterns of disease spread within crops. In addition to dispersal by flight and within canopy movement, aphid species may walk over and colonize plants from the bare soil (Alyokhin and Sewell 2003). Many models of vectored plant virus epidemics assume a constant vector population size and ignore explicit birth and death processes (Jeger et al. 1998), although these models can be expanded to account for this temporal variability (Madden et al. 2000b); in the latter case, numerical simulations are generally needed to obtain insight from the models. Models with the assumption of constant size (births balance deaths) were compared with those in which logistic vector growth was included (Sisterson and Stenger 2016). With logistic growth, increasing mortality decreased overall population size and the percentage of viruliferous vectors. There is a need to integrate realistic vector population dynamic models into epidemiological models as identified in the concluding section and Box 3.

In the epidemiological models above, inoculation rates are assumed to be directly proportional to the susceptible host plant density and the abundance or frequency of viruliferous vectors, and acquisition to the infected host plant density and nonviruliferous vectors. Spatial aggregation (Madden et al. 1987b) of vectors was found to be an inevitable consequence of infection in theoretical modeling, which is in agreement with empirical observations (e.g., Madden et al. 1987b, 1988). Aggregation may support disease spread through increased emigration caused by aggregation, but within a crop, aggregation can reduce the contact rate between plants and vectors and hence the infection rate when compared with a model based on direct proportionality (Zhang et al. 2000b). Most epidemiological models also assume a constant feeding rate by vectors, whereas for persistently transmitted viruses, a minimum feeding period is required and the feeding period may be variable (Grilli and Holt 2000) (Fig. 9). The model suggested that genetic change in host or vector, leading to an increase in variability of the feeding period, could have unexpected consequences for disease dynamics.

Indirect induced effects. Other effects on disease dynamics arise from changes induced in the vector either by the status of the host, healthy of infected, or by whether the vector is viruliferous. For the host, volatile compounds emitted following infection by the persistently transmitted Potato leaf roll virus (PLRV) and subsequent disease progression potentially explain the behavioral responses of Myzus persicae in their preferential settlement on potato leaves (Werner et al. 2009). However, there was no difference found in aphid attraction between PLRV-infected and noninfected young apical leaves arising from headspace volatiles (Alvarez et al. 2007). Attraction was however present in mature leaves. CMV induces changes in cucumber that modifies the alighting, settling, and probing of Aphis gossypii, leading to increased transmission and spread, relevant for the modeling of viruses transmitted in a nonpersistent manner (Carmo-Sousa et al. 2014). Plant chemistry has been shown to play a major role in these effects for nonpersistent viruses by reducing plant quality for aphids but also through attraction to volatiles produced by infected plants (Mauck et al. 2014a, b). A different perspective applies to persistently transmitted viruses where host plants must provide sufficient host quality for the vector for extended periods of feeding before dispersing to a healthy host (Mauck et al. 2012). Stylet penetration behavior of $M$. persicae on infected and noninfected Ipomeas spp. was studied (Wosula et al. 2014). Infection with potyviruses has been shown to increase the intrinsic rate of increase of the aphid on sweet potato. However, for members of the morning glory family commonly found around sweet potato fields, 
stylet penetration behavior, unlike that on sweet potato, was shown to have less preference for infected plants.

For the vector, potentially viruliferous thrips (Frankliniella fusca) laid more eggs that nonviruliferous thrips on peanut; however, fewer larvae developed into adults and those that did require a longer developmental time (Shrestha et al. 2012). Taken together, these opposing effects suggest a trade-off in terms of disease dynamics. Vector behavior can be manipulated by acquiring virus. TYLCV induced a less-mobile behavior in $B$. tabaci in which viruliferous whiteflies remained in one position on tomato leaves for longer and sustained a longer sap ingestion period than nonviruliferous whiteflies (MorenoDelafuente et al. 2013). Thus, TYLCV increases feeding behavior and the inoculation efficiency of the vector by manipulating the whitefly vector; it seems that the TYLCV-B. tabaci interaction is mutually beneficial to vector and virus. This point of view was also expressed by Hodge and Powell (2010) with respect to the bean aphid Acyrthosiphon pisum, the vector of Pea enation virus.

A major finding in recent years has been that vector preference for diseased or healthy plants depends on whether the vector is viruliferous or nonviruliferous, and such preferences have recently been modeled. Incorporating this phenomenon into a model, it was found that such conditional preference increases virus spread throughout an epidemic from the time there are few diseased plants to the time when they are abundant (Roosien et al. 2013). Key to this increase was the switch in preference from diseased to healthy plants following acquisition of the virus, i.e., preference was condition-dependent. Recently, Shaw et al. (2017) linked condition-dependent preferences to vector population growth and movement behavior to explore how vector traits influenced rates of disease spread. Although vector growth rate had the greatest influence, condition-dependent dispersal rate was also an important factor. Vector preference for diseased or healthy host plants has long been recognized and has recently been modeled. Zeilinger and Daugherty (2014) investigated the interaction between vector preference and host resistance or tolerance to infection in a series of models. In the models, vectors cannot acquire virus from resistant plants but can from tolerant plants. When vectors preferred diseased plants, tolerance reduced disease levels compared with susceptible plants. When vectors avoided diseased plants, tolerance increased disease levels. However, both forms of defense increased pathogen spill-over to healthy plants if vectors preferred diseased plants. For TSWV, thrips preferential behavior affected by virus acquisition was modeled and shown to lead to enhanced transmission to healthy plants (Ogada et al. 2016).

Virus-vector interactions and fitness. Viruses affect vector physiology and behavior in ways that enhance transmission to a new host and hence virus fitness, as noted in the previous section.

\section{BOX 3}

\section{Gaps in current modeling effort in plant virus epidemiology and prospects for future research}

There are currently gaps in understanding the effects of both large-scale and more local circumstances on plant virus diseases, epidemic development, and disease control. Future modeling effort can assist research in:

- Identifying the consequences of large-scale climatic fluctuations, including global warming, for plant virus epidemics and shifts in virus and vector distributions;

- Basing control of plant virus epidemics on locale-specific conditions, including crop, landscape and farmer heterogeneity, and interactions; and by so doing contribute to improved methods of disease control.

Disentangling the interactions between viruses, vectors, host plants, and the biotic and abiotic environment presents major challenges for experimental and epidemiological studies, where typically pairwise interactions are the norm. Some advances have been made by modelers in meeting these challenges, but more can realistically be achieved. In particular by:

- Integrating vector population dynamics and ecology into epidemiological models in a more realistic way, specifically, by recognizing that virus transmission and transmission type may affect vector life history parameters, and flight, landing, and feeding behavior; and

- Developing evolutionary models for viruses, vectors, and the virus-vector interaction based on fitness trade-offs and other population genetic approaches. Can viruses manipulate vectors, natural enemies, and host plants to enhance their fitness? How best to characterize virus-virus interactions within plants as synergistic, neutral, or antagonistic?

Finally, we note that advances in statistical and computational techniques should facilitate a greater interrogation of observational data, simultaneous estimation of epidemiological parameters, and evaluating the relative importance in determining the epidemic outcomes.
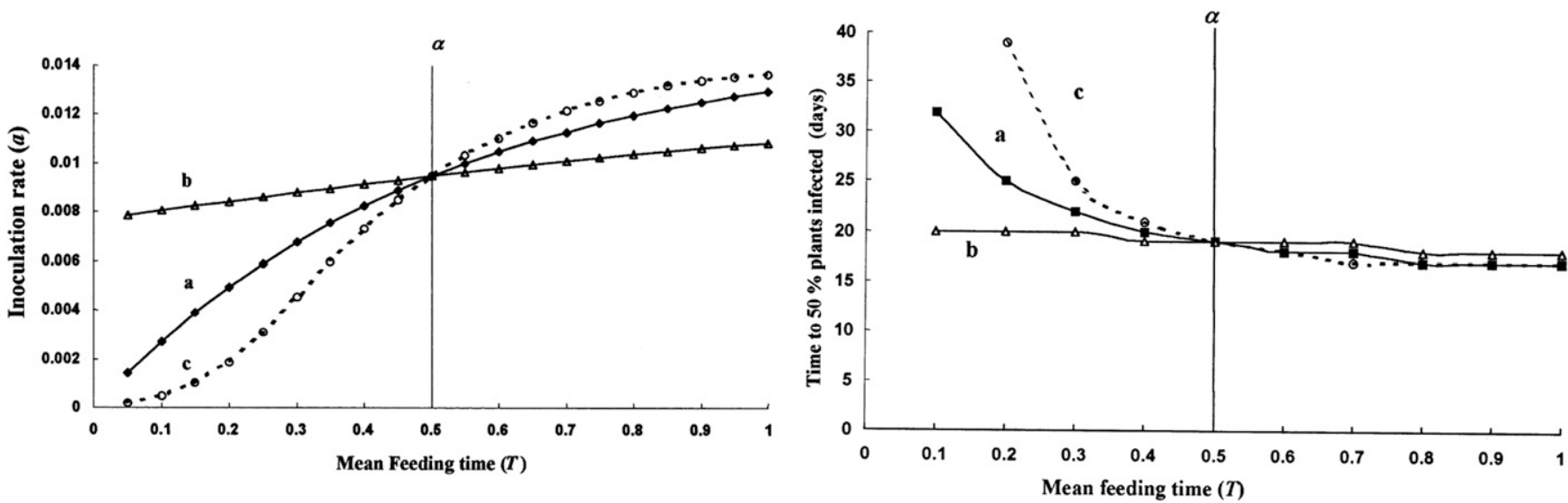

Fig. 9. (Left) Relationship between virus inoculation rate and vector feeding period with constant or variable feeding periods: labeled as (a) constant feeding period, (b) no minimum feeding time with high standard deviation, (c) nonzero feeding time with low standard deviation. (Right) Time to $50 \%$ plants infected in relation to mean feeding time for constant and variable feeding periods (lines labeled as in the left graph) (Figs. 1 and 3 in Grilli and Holt 2000, reprinted with permission from Elsevier). 
The reciprocal effect in which vector life history affects the virus within infected plants has been less studied (Gutiérrez et al. 2013), in particular, how the feeding habits of vectors and vector-related stresses affect the behavior of viruses in plants and hence transmission efficiency. Life expectancy of vectors can be affected by virusinduced preferential behavior and leads to improved fitness, promoting increased spread of the virus within a crop (Ogada et al. 2016). Feeding behavior of viruliferous Sogatella furcifera, the vector of SRBSDV, differed from that observed when nonviruliferous (Xu et al. 2014b). When both parents were viruliferous, fecundity and egg hatchability were lower than with nonviruliferous parents. If one parent was viruliferous, there were no significant effects. It was concluded that virus effects on plant host-vector interactions could influence competition between coinfecting potyviruses (Salvaudon et al. 2013). Modeling could contribute to future research on how vector life history leads to virus fitness effects.

\section{Tritrophic Interactions}

The tripartite virus-vector-host system gains a tritrophic element when natural enemies of the vector are present (Jeger et al. 2012), whether parasitoids, predators, or entomopathogens (Fig. 10). Parasitoids have been used as biocontrol agents of CMD with varying levels of success depending on the time after planting cassava (Otim et al. 2006). Highly efficient parasitoids and predators can be effective biocontrol agents but entomopathogens need to be both virulent and highly transmissible (Okamoto and Amarasekare 2012). However, these workers found that inundation with a natural enemy did not reduce disease incidence, whereas inundation with a competitor had a large effect in reducing disease incidence. Such tritrophic interactions may be manipulated by the virus to increase their fitness, and models have been proposed for the interaction with parasitoids (Jeger et al. 2011a).

Biological control of virus vectors using natural enemies can reduce vector densities but may have indirect effects on temporal and spatial disease spread. That parasitoids aid dispersal of a nonpersistently transmitted virus by vector dispersal was shown by Hodge et al. (2011) for Bean yellow mosaic virus transmitted by the pea aphid Acyrthosiphon pisum. Higher rates of parasitism of M. persicae were observed on infected Cucurbita pepo infected with CMV compared with healthy plants (Mauck et al. 2015a). It was argued that the reduced nutritional quality of infected plants compromised their ability to mount a defense against the parasitoid Aphidius colemani. CMV-related changes in plant chemistry affect vector behavior sufficiently to enhance virus transmission. Distribution patterns of CMV and Cucurbit aphid-borne yellows virus (CABYV), the latter transmitted in a persistent manner, were also compared with those of the vector in the presence of $A$. colemani (Dáder et al. 2012). Parasitoids enhance the spread of CMV in the short term, although parasitism had potential benefits in the long term. For the persistent CABYV, A. colemani limited spread and disease incidence in the long term. The egg parasitoid Anagrus nilaparvatae of the rice brown planthopper Nilaparvata lugens was attracted to plants with plant hopper eggs (Xu et al. 2014a); however, there was no preference for plants infected by Rice black-streaked dwarf virus (RBSDV) compared with healthy plants when both harbored eggs. Developmental time of immature male parasitoids in eggs on RBSDV-infected plants was longer than on healthy plants, but not with females.

For predators, Zhou and Yao (2014a, b) developed a mathematical model linking a host-vector disease model with a predator-vector model and showed that introduction of a predator may suppress the spread of vector-borne viruses, although the disease can persist. However, Belliure et al. (2011) provided evidence to support that antipredator behavior by $M$. persicae might affect its dispersal and hence virus spread even though transmission efficiency was no higher than without the predator, at least for coccinelid beetles. Predators are also able to locate herbivorous prey (vector and nonvector) on infected plants as efficiently as on healthy plants (Mauck et al. 2015b). In insect-proof cages, the effect of aphidophagous predators on the spread of CMV, transmitted in a nonpersistent manner by A. gossypii, was found to be restricted to the virus-infected central plant (Garzón et al. 2015). The distribution patterns of CMV and the aphid were only coincident around the central plant. Zhou and Yao

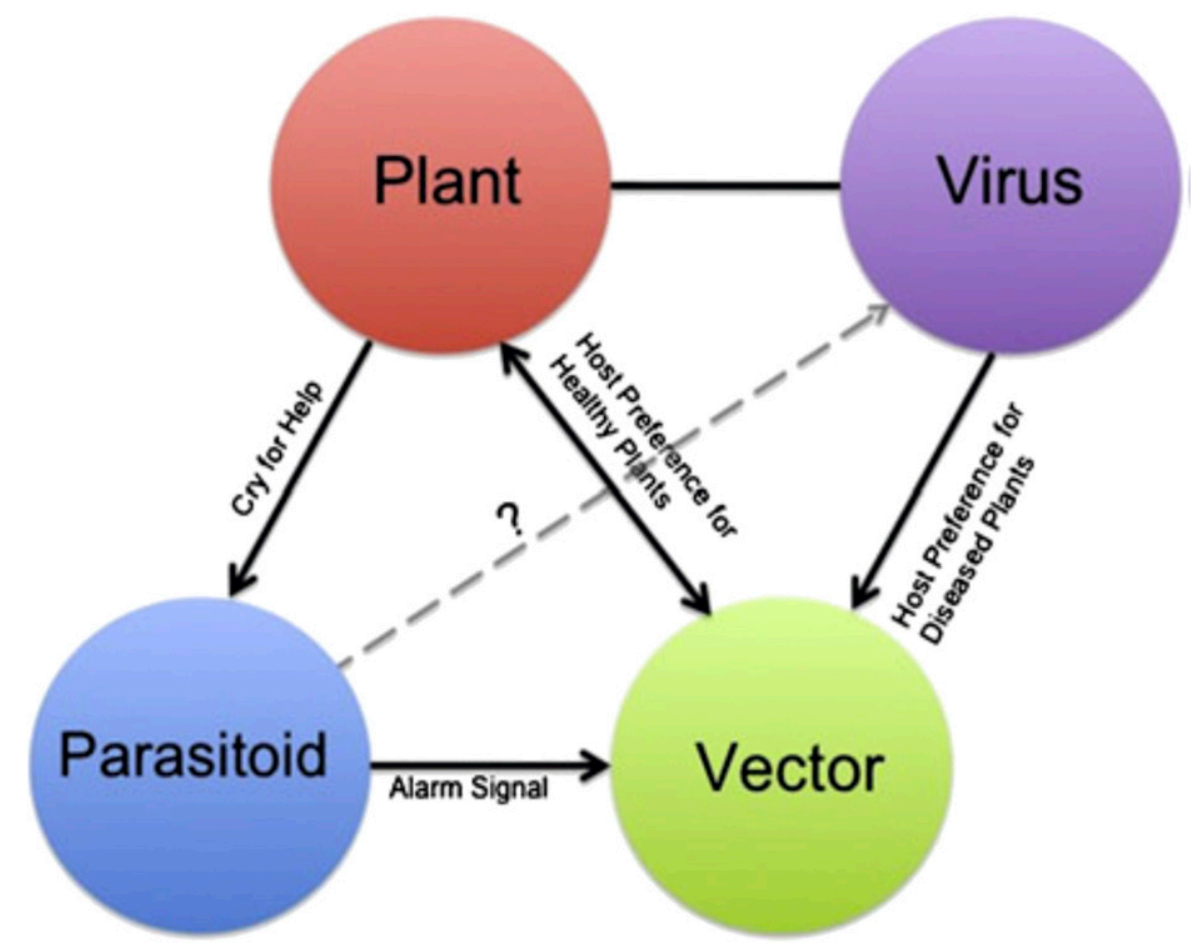

Fig. 10. Schematic representation of a tritrophic plant-virus-vector-parasitoid relationship where a combination of signaling devices manipulates the interaction (Fig. 1 in Jeger et al. 2012, copyright KNPV, with permission of Springer): (i) the vector shows preference for either healthy or infected host plants, (ii) the host plant uses a "cry-for-help" signal to attract parasitoids, (iii) the presence of the parasitoid induces an alarm signal initiating vector movement, including to other plants. The crucial element in increasing virus fitness (transmission) is that there is a switch in vector preference upon the change in vector status: i.e., nonviriluferous vectors prefer infected plants and acquire virus; upon acquisition, viruliferous vectors prefer (and inoculate) healthy plants. 
(2014a, b) used the basic reproduction number for systems with and without predators for a host-vector disease model. The further development of vector-based population dynamic models for virus diseases could help elucidate the importance of tritrophic interactions in disease dynamics, as noted for TSWV, vectored by Frankliniella occidentalis (Ogada et al. 2016). Increased generalist predator richness reduced the population density of the aphid vectors of CYDV in wheat and that virus incidence was also reduced when predators were present, but not related to richness (Long and Finke 2015). Predators did stimulate vector movement, but this was likely to reduce feeding time and hence transmission efficiency for this persistently transmitted virus. Finke (2012) points out that the effects of predators on herbivore vectors depend on whether there is a consumptive effect (by consuming viruliferous vectors) or a nonconsumptive effect (inducing antipredator behavior).

Modeling has proved to be a productive area for investigating tritrophic interactions complementing experimental studies. It has been argued that future modeling studies should deal with interaction webs (Eubanks and Finke 2014), where there are pathogens, herbivores, herbivores as vectors, and other interacting insects including predators and parasitoids, with direct and indirect effects on crop yield.

\section{Conclusions}

Plant virus epidemiology has matured as a distinctive area of research endeavor over the last 30 years (Jones 2014; McLean et al. 1986; Thresh 2006). Major advances have been made in disentangling the interaction between host plants and viruses, host plants and virus vectors, and between plant viruses and vectors. These interactions, manifest at different hierarchical levels from within-cell processes to production systems and landscape features, are a defining feature of plant virus epidemics. Plants may be coinfected with different viruses or virus strains, and the consequences for disease expression and dynamics range from beneficial to attenuation. Major advances have been made in understanding how transmission processes are affected by vector behavior, dispersal, and ecology. A plant virus may have multiple hosts (including noncrop plants) and multiple vectors (each of which may also transmit other viruses), and in these cases a broader appreciation of the agricultural and ecological context has become apparent. And yet, this knowledge is thus far incomplete. We can identify what in our view is missing from current modeling efforts and the prospects for future research to fill these gaps (Box 3).

Overall, what mathematical modeling has to offer is: (1) a means of integrating interactions between virus, vector, host plant, and the biotic and abiotic environment at different levels; (2) asking the question, suppose a particular effect is determined at one level, what are the consequences at a higher level?; (3) evaluating alternative scenarios for disease control; and (4) contributing more generally to the ecology of vectored diseases, where similar considerations apply in plant, animal, and human health.

\section{Acknowledgments}

The authors wish to acknowledge the long-term interest and encouragement of John Michael Thresh (deceased 2015) in the appreciation, development, and uses of mathematical modeling in plant virus epidemiology, a discipline which he fostered throughout a long and productive career and made seminal contributions (Irwin and Fereres 2017). We thank the two reviewers for their constructive and encouraging comments.

\section{Literature Cited}

Alexander, H. M., Bruns, E., Schebor, H., and Malmstrom, C. M. 2017. Cropassociated virus infection in a native perennial grass: reduction in plant fitness and dynamic patterns of virus detection. J. Ecol. 105:1021-1031.

Alexander, H. M., Mauck, K. E., Whitfield, A. E., Garrett, K. A., and Malmstrom, C. M. 2014. Plant-virus interactions and the agro-ecological interface. Eur. J. Plant Pathol. 138:529-547.

Alonso-Prados, J. L., Luis-Arteaga, M., Alvarez, J. M., Moriones, E., Batlle, A., Lavina, A., García-Arenal, F., and Fraile, A. 2003. Epidemics of aphidtransmitted viruses in melon crops in Spain. Eur. J. Plant Pathol. 109: 129-138.
Alvarez, A. E., Garzo, E., Verbeek, M., Vosman, B., Dicke, M., and Tjallingii, W. F. 2007. Infection of potato plants with potato leafroll virus changes attraction and feeding behavior of Myzus persicae. Entomol. Exp. Appl. 125:135-144.

Alyokhin, A., and Sewell, G. 2003. On-soil movement and plant colonization by walking wingless morphs of three aphid species (Homoptera: Aphididae) in greenhouse arenas. Environ. Entomol. 32:1393-1398.

Anguelov, R., Lubuma, J., and Dumont, Y. 2012. Mathematical analysis of vectorborne diseases on plants. Pages 22-29 in: 2012 IEEE $4^{\text {th }}$ Int. Symp. Plant Growth Model. Simul. Vis. Appl. (PMA). M. Kang, Y. Dumont, and Y. Guo, eds.

Arguello-Astorga, G., Ascencio-Ibanez, J. T., Dallas, M. B., Orozco, B. M., and Hanley-Bowdoin, L. 2007. High-frequency reversion of geminivirus replication protein mutants during infection. J. Virol. 81:11005-11015.

Ariyo, O. A., Dixon, A. G. O., and Atiri, G. I. 2005. Whitefly Bemisia tabaci (Homoptera: Aleyrodidae) infestation on cassava genotypes grown at different ecozones in Nigeria. J. Econ. Entomol. 98:611-617.

Atallah, S. S., Gomez, M. I., Conrad, J. M., and Nyrop, J. P. 2015. A plant-level, spatial, bioeconomic model of plant disease diffusion and control: grapevine leafroll disease. Am. J. Agric. Econ. 97:199-218.

Bao, X. D., and Roossinck, M. J. 2013. A life history view of mutualistic viral symbiosis: quantity or quality for cooperation. Curr. Opin. Microbiol. 16 514-518.

Bebber, D. P. 2015. Range-expanding pests and pathogens in a warming world Annu. Rev. Phytopathol. 53:335-356.

Belliure, B., Amoros-Jimenez, R., Fereres, A., and Marcos-García, M. A. 2011 Antipredator behavior of Myzus persicae affects transmission efficiency of Broad bean wilt virus 1. Virus Res. 159:206-214.

Berzitis, E. A., Jordan, N., Minigan, R. H., Hallett, R. H., and Newman, J. A. 2014 Climate and host plant availability impact the future distribution of the bean leaf beetle (Cerotoma trifurcate). Glob. Change Biol. 20:2778-2792.

Betancourt, M., Escrui, F., Fraile, A., and García-Arenal, F. 2013. Virulence evolution of a generalist plant virus in a heterogeneous host system. Evol. Appl. 6:875-890.

Boag, B., Evans, K. A., Yeates, G. W., Brown, D. F. G., and Neilson, R. 1997 Global potential distribution of European longidorid virus-vector nematodes. Nematologica 43:99-106.

Boissot, N., Reynaud, B., and Letourmy, P. 1998. Temporal analysis of western flower thrips (Thysanoptera: Thripidae) population dynamics on Reunion Island. Environ. Entomol. 27:1437-1443.

Borer, E. T., Adams, V. T., Engler, G. A., Adams, A. L., Schumann, C. B., and Seabloom, E. W. 2009. Aphid fecundity and grassland invasion: Invader life history is the key. Ecol. Appl. 19:1187-1196.

Bouwmeester, H., Heuvelink, G. M. B., Legg, J. P., and Stoorvogel, J. J. 2012. Comparison of disease patterns assessed by three independent surveys of cassava mosaic virus disease in Rwanda and Burundi. Plant Pathol. 61: 399-412.

Brown, D. H., and Bolker, B. M. 2004. The effects of disease dispersal and host clustering on the epidemic threshold in plants. Bull. Math. Biol. 66:341-371.

Buddenhagen, I. W. 1983. Crop improvement in relation to virus diseases and their epidemiology. Pages 25-37 in: Plant Virus Epidemiology: The Spread and Control of Insect-borne Viruses. R. T. Plumb and J. M. Plumb, eds. Blackwell Scientific Publications, Oxford, U.K.

Burrows, M., Thomas, C., McRoberts, N., Bostock, R. M., Coop, L., and Stack, J. 2016. Coordination of diagnostic efforts in the Great Plains: wheat virus survey and modeling of disease onset. Plant Dis. 100:1037-1045.

Canto, T., Aranda, M. A., and Fereres, A. 2009. Climate change effects on physiology and population processes of hosts and vectors that influence the spread of hemipteran-borne plant viruses. Glob. Change Biol. 15:1884-1894.

Carmo-Sousa, M., Moreno, A., Garzo, E., and Fereres, A. 2014. A non-persistently transmitted-virus induces a pull-push strategy in its aphid vector to optimize transmission and spread. Virus Res. 186:38-46.

Chan, M. S., and Jeger, M. J. 1994. An analytical model of plant-virus disease dynamics with roguing and replanting. J. Appl. Ecol. 31:413-427.

Chappell, T. M., Beaudoin, A. L. P., and Kennedy, G. G. 2013. Interacting virus abundance and transmission intensity underlie Tomato spotted wilt virus incidence: an example weather-based model for cultivated tobacco. PLoS One 8:e73321.

Chew, Y. H., Smith, R. W., Jones, H. J., Seaton, D. D., Grima, R., and Halliday, K. J. 2014. Mathematical models light up plant signaling. Plant Cell 26:5-20.

Colvin, J., Fishpool, L. D. C., Fargette, D., Sherington, J., and Fauquet, C. 1998. Bemisia tabaci (Hemiptera: Aleyrodidae) trap catches in a cassava field in Cote d'Ivoire in relation to environmental factors and the distribution of African cassava mosaic disease. Bull. Entomol. Res. 88:369-378.

Coutts, B. A., Thomas-Carroll, M. L., and Jones, R. A. C. 2004. Analysing spatial patterns of spread of Lettuce necrotic yellows virus and Lettuce big-vein disease in lettuce field plantings. Ann. Appl. Biol. 145:339-343.

Cronin, J. P., Rúa, M. A., and Mitchell, C. E. 2014. Why is living fast dangerous? Disentangling the roles of resistance and tolerance of disease. Am. Nat. 184: 172-187.

Culbreath, A. K., and Srinivasan, R. 2011. Epidemiology of spotted wilt disease of peanut caused by Tomato spotted wilt virus in the southeastern U.S. Virus Res. 159:101-109.

Cunniffe, N. J., Koskella, B., Metcalf, C. J. E., Parnell, S., Gottwald, T. R., and Gilligan, C. A. 2015. Thirteen challenges in modelling plant diseases. Epidemics 10:6-10. 
Cunniffe, N. J., Laranjeira, F. F., Neri, M. M., DeSimone, R. E., and Gilligan, C. A. 2014. Cost-effective control of plant disease when epidemiological knowledge is incomplete: Modelling Bahia bark scaling of citrus. PLoS Comp. Biol. 10: e1003753.

Dáder, B., Moreno, A., Vinuela, E., and Fereres, A. 2012. Spatio-temporal dynamics of viruses are differentially affected by parasitoids depending on the mode of transmission. Viruses-Basel 4:3069-3089.

Dallot, S., Gottwald, T., Labonne, G., and Quiot, J. B. 2004. Factors affecting the spread of Plum pox virus strain $\mathrm{M}$ in peach orchards subjected to roguing in France. Phytopathology 94:1390-1398.

Desbiez, C., Mourly, B., and Lecoq, H. 2011. The hallmarks of "green" viruses. Do plant viruses evolve differently from the others? Infect. Genet. Evol. 11: 812-824.

Döring, T. F. 2011. Potential and limitations of plant virus epidemiology: lessons from the Potato virus Y pathosystem. Potato Res. 54:341-354.

Dusi, A. N., Peters, D., and van der Werf, W. 2000. Measuring and modelling the effects of inoculation date and aphid flights on the secondary spread of Beet mosaic virus in sugar beet. Ann. Appl. Biol. 136:131-146.

Edelstein-Keshet, L. 1988. Mathematical Models in Biology. Random House/ Birkhauser Mathematics Series. Random House USA, New York.

Ehrlén, J., Morris, W. F., von Euler, T., and Dahlgren, J. P. 2016. Advancing environmentally explicit structured population models of plants. J. Ecol. 104: 292-305.

Elena, S. F., Fraile, A., and García-Arenal, F. 2014. Evolution and emergence of plant viruses. Adv. Virus Res. 88:161-191.

Eubanks, M. D., and Finke, D. L. 2014. Interaction webs in agroecosystems: beyond who eats whom. Curr. Opin. Insect Sci. 2014:1-6.

Fabre, F., Bruchou, C., Palloix, A., and Moury, B. 2009. Key determinants of resistance durability to plant viruses: insights from a model linking withinand between-host dynamics. Virus Res. 141:140-149.

Fabre, F., Rousseau, E., Mailleret, L., and Moury, B. 2012. Durable strategies to deploy plant resistance in agricultural landscapes. New Phytol. 193: 1064-1075.

Fargalla, F. H., Taha, A. M., and Fahim, M. A. 2011. Epidemiology of Tomato yellow leaf curl virus in relation to intercropping and insecticidal spray effects on the Bemisia tabaci under field conditions. Acta Hortic.: 331-336.

Fargette, D., Jeger, M. J., Fauquet, C., and Fishpool, L. D. C. 1994. Analysis of temporal disease progress of African cassava mosaic virus. Phytopathology 84:91-98.

Fargette, D., Konate, G., Fauquet, C., Muller, E., Peterschmitt, M., and Thresh, J. M. 2006. Molecular ecology and emergence of tropical plant viruses. Annu. Rev. Phytopathol. 44:235-260.

Fargette, D., and Vié, K. 1995. Simulation of the effects of host-resistance, reversion, and cutting selection on incidence of African cassava mosaic virus and yield losses in cassava. Phytopathology 85:370-375.

Finke, D. L. 2012. Contrasting the consumptive and non-consumptive cascading effects of natural enemies on vector-borne pathogens. Entomol. Exp. Appl. 144: 45-55.

Fondong, V. N., Thresh, J. M., and Zok, S. 2002. Spatial and temporal spread of cassava mosaic virus disease in cassava grown alone and when intercropped with maize and/or cowpea. J. Phytopathol. 150:365-374.

Fraile, A., and García-Arenal, F. 2010. The coevolution of plants and viruses: resistance and pathogenicity. Adv. Virus Res. 76:1-32.

Gani, J., and Stals, L. 2004. The spread of a viral infection in a plantation. Environmetrics 15:555-560.

Gani, J., and Stals, L. 2005. A continuous time Markov chain model for a plantation-nursery system. Environmetrics 16:849-861.

Gao, S. J., Xia, L. J., Liu, Y., and Xie, D. H. 2015. A plant virus disease model with periodic environment and pulse roguing. Stud. Appl. Math. 136:357-381.

García-Andrés, S., Tomás, D. M., Navas-Castillo, J., and Moriones, E. 2009. Resistance-driven selection of begomoviruses associated with the tomato yellow leaf curl disease. Virus Res. 146:66-72.

García-Arenal, F., and Fraile, A. 2013. Trade-offs in host range evolution of plant viruses. Plant Pathol. 62:2-9.

Garzón, A., Budia, F., Medina, P., Morales, I., Fereres, A., and Vinuela, E. 2015. The effect of Chrysoperla carnea (Neuroptera:Chrysopidae) and Adalia bipunctata (Coleoptera: Coccinellidae) on the spread of cucumber mosaic virus (CMV) by Aphis gossypii (Hemiptera: Aphididae). Bull. Entomol. Res. 105:13-22.

Gibson, G. J. 1997. Investigating mechanisms of spatiotemporal epidemic spread using stochastic models. Phytopathology 87:139-146.

Gilligan, C. A., and van den Bosch, F. 2008. Epidemiological models for invasion and persistence of pathogens. Annu. Rev. Phytopathol. 46:385-418.

Gottwald, T. R., Cambra, M., Moreno, P., Camasara, E., and Piquer, J. 1996. Spatial and temporal analysis of citrus tristeza virus in Eastern Spain. Phytopathology 86:45-55.

Grilli, M. P., and Holt, J. 2000. Vector feeding period variability in epidemiological models of persistent plant viruses. Ecol. Modell. 126:49-57.

Gutiérrez, S., Michalakis, Y., van Munster, M., and Blanc, S. 2013. Plant feeding by insect vectors can affect life cycle, population genetics and evolution of plant viruses. Funct. Ecol. 27:610-622.

Hamelin, F. M., Allen, L. J. S., Prenderville, H. R., Hajimorad, M. R., and Jeger, M. J. 2016. The evolution of plant virus transmission pathways. J. Theor. Biol. 396:75-89.
Hamelin, F. M., Hilker, F. M., Sun, T. A., Jeger, M. J., Hajimorad, M. R., Allen, L. J. S., and Prendeville, H. R. 2017. The evolution of parasitic and mutualistic plant-virus symbioses through transmission-virulence trade-offs. Virus Res. 241:77-87.

Hilker, F. M., Allen, L. J. S., Bokil, V. A., Briggs, C. J., Feng, Z., Garrett, K. A., Gross, L. J., Hamelin, F. M., Jeger, M. J., Manore, C., Power, A. G., Redinbaugh, M. G., Rúa, M. A., and Cunniffe, N. J. 2017. Modeling virus coinfection to inform management of maize lethal necrosis in Kenya. Phytopathology 107:1095-1108.

Hily, J. M., García, A., Moreno, A., Plaza, M., Wilkinson, M. D., Fereres, A., Fraile, A., and García-Arenal, F. 2014. The relationship between host lifespan and pathogen reservoir potential: an analysis in the system Arabidopsis thaliana-Cucumber mosaic virus. PLoS Pathog 10:e1004492.

Hily, J. M., Poulicard, N., Mora, M. A., Pagán, P., and García-Arenal, F. 2016 Environment and host genotype determine the outcome of a plant-virus interaction from antagonism to mutualism. New Phytol. 209:812-822.

Hodge, S., Hardie, J., and Powell, G. 2011. Parasitoids aid dispersal of a nonpersistently transmitted plant virus by disturbing the aphid vector. Agric. For. Entomol. 13:83-88.

Hodge, S., and Powell, G. 2010. Conditional facilitation of an aphid vector, Acyrthrosyphon pisum, by the plant pathogen, pea enation virus. J. Insect Sci. 10:155.

Holt, J., and Chancellor, T. C. B. 1996. Simulation modelling of the spread of rice tungro virus disease: the potential for management by roguing. J. Appl. Ecol. 33:927-936.

Holt, J., Colvin, J., and Muniyappa, V. 1999. Identifying control strategies for tomato leaf curl virus disease using an epidemiological model. J. Appl. Ecol. 36:625-633.

Holt, J., Jeger, M. J., Thresh, J. M., and Otim-Nape, G. W. 1997. An epidemiological model incorporating vector population dynamics applied to African cassava mosaic virus disease. J. Appl. Ecol. 34:793-806.

Holt, J., Pavis, C., Marquier, M., Chancellor, T. C. B., Urbino, C., and Boissot, N 2008. Insect-screened cultivation to reduce the invasion of tomato crops by Bemisia tabaci: modelling the impact of on virus disease and vector. Agric. For. Meteorol. 10:61-67.

Irwin, M. E., and Fereres, A. 2017. John Michael Thresh, founding father of plant virus epidemiology: A tribute. Virus Res. 241:3-9.

Jabłońska-Sabuka, M., Kalaria, R., and Kauranne, T. 2015. A dynamical model for epidemic outbursts by begomovirus population clusters. Ecol. Modell. 297:60-68.

Jeger, M. J., Chen, Z., Cunningham, E., Martin, G., and Powell, G. 2012. Population biology and epidemiology of plant virus epidemics: from tripartite to tritrophic interactions. Eur. J. Plant Pathol. 133:3-23.

Jeger, M. J., Chen, Z., Powell, G., Hodge, S., and van den Bosch, F. 2011a Interactions in a host plant -virus-vector-parasitoid system: modelling the consequences for virus transmission and disease dynamics. Virus Res. 159 183-193.

Jeger, M. J., Holt, J., van den Bosch, F., and Madden, L. V. 2004. Epidemiology of insect-transmitted plant viruses: Modelling disease dynamics and control interventions. Physiol. Entomol. 29:291-304.

Jeger, M. J., Madden, L. V., and van den Bosch, F. 2009. The effect of transmission route on plant virus epidemic development and disease control. J. Theor. Biol. 258:198-207.

Jeger, M. J., Stevenson, K. L., and Madden, L. V. 2017. Plant disease epidemiology. Oxford Bibliographies. http://oxfordbibliographiesonline.com/

Jeger, M. J., and Thresh, J. M. 1993. Modelling reinfection of replanted cocoa by swollen shoot virus in pandemically diseased areas. J. Appl. Ecol. 30:187-196.

Jeger, M. J., van den Bosch, F., and Madden, L. V. 2011 b. Modelling virus- and host-limitation in vectored plant disease epidemics. Virus Res. 159:215-222.

Jeger, M. J., van den Bosch, F., Madden, L. V., and Holt, J. 1998. A model for analysing plant-virus transmission characteristics and epidemic development. IMA J. Math. Appl. Med. Biol. 15:1-18.

Jeger, M. J., van den Bosch, F., and McRoberts, N. 2015. Modelling transmission characteristics and epidemic development of the tospovirus-thrip interaction. Arthropod-Plant Interact. 9:107-120.

Jones, R. A. C. 2014. Trends in plant virus epidemiology: opportunities from new or improved technologies. Virus Res. 186:3-19.

Jones, R. A. C., Salam, M. U., Maling, T. J., Diggle, A. J., and Thackray, D. J. 2010. Principles of predicting plant virus disease epidemics. Annu. Rev. Phytopathol. 48:179-203.

Katis, N. I., Tsitsipis, J. A., Lykouressis, D. P., Papapanayotou, A., Margaritopolous, J. T., Kokinis, G. M., Perdikis, D. C., and Manoussopoulos, I. N. 2006. Transmission of Zucchini yellow mosaic virus by colonizing and non-colonizing aphids in Greece and new aphid species vectors of the virus. J. Phytopathol. 154 293-302.

Kaye, A. C., Moyer, J. W., Parks, E. J., Carbone, I., and Cubeta, M. A. 2011 Population genetic analysis of Tomato spotted wilt virus on peanut in North Carolina and Virginia. Phytopathology 101:147-153.

Kim, J., Kil, E. J., Kim, S., Seo, H., Byun, H. S., Park, J., Chung, M. N., Kwak, H. R., Kim, M. K., Kim, C. S., Yang, J. W., Lee, K. Y., Choi, H. S., and Lee, S 2015. Seed transmission of Sweet potato leaf curl virus in sweet potato (Ipomea batatas). Plant Pathol. 64:1284-1291.

Legg, J. P., French, R., Rogan, D., Okao-Okuja, G., and Brown, J. K. 2002. A distinct Bemisia tabaci (Gennadius) (Hemiptera: Sternorrhyncha: Aleyrodidae) genotype cluster is associated with the epidemic of severe cassava mosaic virus disease in Uganda. Mol. Ecol. 11:1219-1229. 


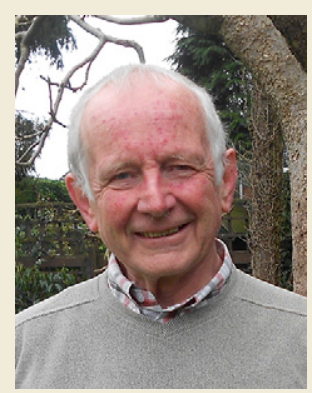

\section{Michael Jeger}

Michael Jeger is an emeritus professor at Imperial College London, U.K., and since 2010 a senior research investigator in the Centre for Environmental Policy based at the Silwood Park campus. He received a PhD from the University College of Wales, Aberystwyth, in 1979, and worked subsequently at East Malling Research Station, U.K.; Texas A\&M University, U.S.A.; Natural Resources Institute, U.K.; and Wageningen University, the Netherlands; joining Imperial College in 1999. His research interests have been in plant disease epidemiology and modeling across a wide range of pathogen taxa and crop types, both temperate and tropical. Since academic retirement in 2010, personal research has continued with emphasis on analysis of disease spread in plant trade networks, declines and complex diseases of forest trees, plant virus epidemics and vector population dynamics, and increasingly plant health policy. He has served as editor-in-chief of the European Journal of Plant Pathology since 2009, chair of the Plant Health Panel of the European Food Safety Authority (EFSA) since 2009, and on ad hoc committees evaluating and advising U.K. government departments on plant health policy and research.

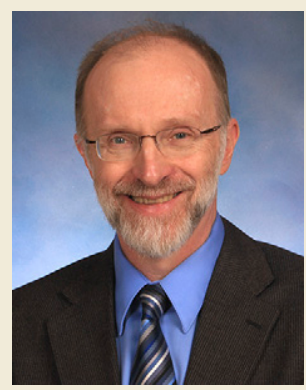

\section{Laurence Madden}

Laurence V. Madden is the distinguished professor of plant protection at The Ohio State University. An authority in plant disease epidemiology, he specializes in the modeling and analysis of plant disease dynamics in time and space. He has a long-term interest in the use of theoretical models to characterize and understand plant virus epidemics, especially in relation to insect vector dynamics. He is an authority on meta-analysis and numerous linear and non-linear mixed modeling methods for data analysis in plant pathology. He has developed many approaches to analyze, compare, and predict plant disease epidemics; characterize the spatial pattern of disease incidence; relate spatial heterogeneity to crop, pathogen, and environmental factors; relate disease dynamics to crop losses and mycotoxin contamination; relate environment to disease and inoculum dynamics; and predict epidemic risk based on environmental variables. He is a former president of the American Phytopathological Society (APS), former editor-in-chief of Phytopathology, and a recipient of several national and international awards.

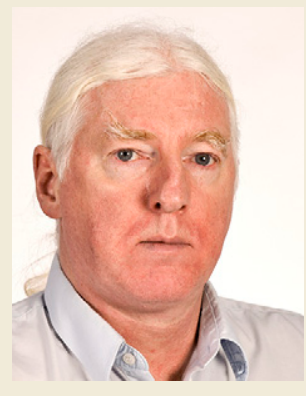

\section{Frank van den Bosch}

Frank van den Bosch is principal investigator at Rothamsted Research. His research group focuses on the development and application of models to study the population dynamics and evolutionary ecology of plants and their pests and pathogens. This work is developed in close collaboration with field and laboratory experimental programs. Some key areas are disease weather relations (methods to quantify the effects of weather variables on the epidemic development of plant pathogens; both statistical data mining techniques and generic mechanistic models have been developed), detection and control of biological invasions (methods to monitor for invading species including early detection and the establishment of pathogen absence; models to quantify the rate of invasion by pests and pathogens including new strains of endemic pests and pathogens), and evolutionary ecology and population genetics (methods to study how pathogen and host life-cycle components affect the evolution of plants and pathogens; the methods developed are applied to climate change, the use of fungicides and cultivar resistance, and the effect of seasonal host dynamics).

Legg, J. P., Jeremiah, S. C., Obiero, H. M., Maruthi, M. N., Ndyetabula, I., OkaoOkuja, G., Bouwmeester, H., Bigirimana, S., Tata-Hangy, W., Gashaka, G., Mkamilo, G., Alicia, T., and Kumar, P. L. 2011. Comparing the regional epidemiology of the cassava mosaic and cassava brown streak virus pandemics in Africa. Virus Res. 159:161-170.

Legg, J. P., and Ogwal, S. 1998. Changes in the incidence of African cassava mosaic virus disease and the abundance of its whitefly vector along southnorth transects in Uganda. J. Appl. Entomol. 122:169-178.

Legg, J. P., and Thresh, J. M. 2000. Cassava mosaic virus disease in East Africa: a dynamic disease in a changing environment. Virus Res. 71:135-149.

Long, E. Y., and Finke, D. L. 2015. Predators indirectly reduce the prevalence of an insect-vectored plant pathogen independent of predator diversity. Oecologia 177:1067-1074.

Luo, Y. L., Gao, S. J., Xie, D. H. and Dai, Y.F. 2015. A discrete plant disease model with roguing and replanting. Adv. Difference Equns. Article number 12 .

Madden, L. V., Hughes, G., and Irwin, M. E. 2000a. Coupling disease-progresscurve and time-of-infection functions for predicting yield loss of crops. Phytopathology 90:788-800.

Madden, L. V., Hughes, G., and van den Bosch, F. 2007. The Study of Plant Disease Epidemics. APS Press, St. Paul, MN.

Madden, L. V., Jeger, M. J., and van den Bosch, F. 2000b. A theoretical assessment of the effects of vector-virus transmission mechanism on plant virus disease epidemics. Phytopathology 90:576-594.

Madden, L. V., Knoke, J. K., and Louie, R. 1983. Classification and prediction of maize dwarf mosaic intensity. Pages 238-242 in: D. T. Gordon, J. K. Knoke, L. R. Nault, and R. M. Ritter, eds. Proc. International Maize Virus Disease Colloquium and Workshop, 2-6 August 1982. The Ohio State University, Wooster, $\mathrm{OH}$.

Madden, L. V., Pirone, T. P., and Raccah, B. 1987a. Temporal analysis of two viruses increasing in the same tobacco field. Phytopathology 77:974-980.

Madden, L. V., Pirone, T. P., and Raccah, B. 1987b. Analysis of spatial patterns of virus-diseased tobacco plants. Phytopathology 77:1409-1417.
Madden, L. V., Raccah, B., and Pirone, T. P. 1990. Modeling plant disease increase as a function of vector numbers: nonpersistent viruses. Res. Pop. Ecol. 32 47-65.

Madden, L. V., Reynolds, K. M., Pirone, T. P., and Raccah, B. 1988. Modeling of tobacco virus epidemics as spatio-temporal autoregressive integrated movingaverage processes. Phytopathology 78:1361-1366.

Marcus, R., and Raccah, B. 1986. Model for the spread of non-persistent virus diseases. J. Appl. Stat. 13:167-175.

Matsukura, K., Towata, T., Sakai, J., Onuki, M., Okuda, M., and Matsumura, M 2013. Dynamics of Southern rice black-streaked dwarf virus in rice and implications for virus acquisition. Phytopathology 103:509-512.

Mauck, K., Bosque-Perez, N. A., Eigenbrode, S. D., de Moraes, C. M., and Mescher, M. C. 2012. Transmission mechanisms shape pathogen effects on host-vector interactions: evidence from plant viruses. Funct. Ecol. 26: $1162-1175$

Mauck, K. E., de Moraes, C. M., Consuelo, M., and Mescher, M. C. 2014a Biochemical and physiological mechanisms underlying effects of Cucumber mosaic virus on host-plant traits that mediate transmission by aphid vectors. Plant Cell Environ. 37:1427-1439.

Mauck, K. E., de Moraes, C. M., and Mescher, M. C. 2014b. Evidence of loca adaptation in plant virus effects on host-vector interactions. Integr. Comp. Biol. 54:193-209.

Mauck, K. E., de Moraes, C. M., and Mescher, M. C. 2015a. Infection of host plants by Cucumber mosaic virus increases the susceptibility of Myzus persicae aphids to the parasitoid Aphidius colemani. Sci. Rep. 5:10963.

Mauck, K. E., Smyers, E., de Moraes, C. M., and Mescher, M. C. 2015b. Virus infection influences host plant interactions with non-vector herbivores and predators. Funct. Ecol. 29:662-673.

Maule, A. J., Caranta, C., and Boulton, M. I. 2007. Sources of natural resistance to plant viruses: status and prospects. Mol. Plant Pathol. 8:223-231.

McLean, G. D., Garrett, R. G., and Ruesink, W. G., eds. 1986. Plant Virus Epidemiology: Monitoring, Modelling, and Predicting Outbreaks. Academic Press, Sydney, Australia. 
McQuaid, C. F., Sseruwagi, P., Pariyo, A., and van den Bosch, F. 2016. Cassava brown streak disease and the sustainability of a clean seed system. Plant Pathol. 65:299-309.

Montarry, J., Cartier, E., Jacquemond, M., Palloix, A., and Moury, B. 2012. Virus adaptation to quantitative plant resistance: erosion or breakdown? J. Evol. Biol. 25:2242-2252.

Moore, S. M., Manore, C. A., Bokil, V. A., Borer, E. T., and Hosseini, P. R. 2011. Spatiotemporal model of barley and cereal yellow dwarf virus transmission dynamics with seasonality and plant competition. Bull. Math. Biol. 73: 2707-2730.

Moreno, A., and Fereres, A. 2012. Virus diseases in lettuce in the Mediterranean basin. Adv. Virus Res. 84:247-288.

Moreno-Delafuente, A., Garzo, E., Moreno, A., and Fereres, A. 2013. A plant virus manipulates the behaviour of its whitefly vector to enhance its transmission efficiency and spread. PLoS One 8:e61543.

Nakazawa, T., Yamanaka, T., and Urana, S. 2012. Model analysis for plant disease dynamics co-mediated by herbivory and herbivore-borne phytopathogens. Biol. Lett. 8:685-688.

Nekoduka, S., Kobayashi, K., Fuji, S., Okuda, M., and Sano, T. 2015. Molecular epidemiology of Impatiens necrotic spot virus on greenhouse ornamental plants in a local area of Japan. J. Gen. Plant Pathol. 81:429-438.

Ogada, P. A., Moualeu, D. P., and Poehling, H. M. 2016. Predictive models for tomato spotted wilt virus spread dynamics, considering Frankliniella occidentalis specific life processes as influenced by the virus. PLoS One 11: $\mathrm{e} 0154533$

Okamoto, K. W., and Amarasekare, P. 2012. The biological control of disease vectors. J. Theor. Biol. 309:47-57.

Ornaghi, J. A., March, G. J., Moschini, R. C., Martinez, M. I., and Boito, G. T. 2011. Predicting population level of Delphacodes kuscheli, vector of Mal de Rio Cuarto virus and climate risk in the Argentine pampas using meteorological models. Trop. Plant Pathol. 36:160-168.

Oro, F. Z., Bonnot, F., Ngo-Bieng, M. A., Delaitre, E., Dufour, B. P., Ametefe, K. E., Mississo, E., Wegbe, K., Muller, E., and Cilas, C. 2012. Spatiotemporal pattern analysis of Cacao swollen shoot virus in experimental plots in Togo. Plant Pathol. 61:1043-1051.

Otim, M., Legg, J., Kyamanywa, S., Polaszek, A., and Gerling, D. 2006. Population dynamics of Bemisia tabaci (Homoptera: Aleyrodidae) parasitoids on cassava mosaic disease-resistant and susceptible varieties. Biocontrol Sci. Technol. 16:205-214

Otim-Nape, G. W., and Thresh, J. M. 1998. The current pandemic of cassava mosaic virus disease in Uganda. Pages 423-443 in: The Epidemiology of Plant Diseases. D. G. Jones, ed. Springer, Dordrecht, the Netherlands.

Otim-Nape, G. W., Thresh, J. M., Bua, A., Baguma, Y., and Shaw, M. W. 1998. Temporal spread of cassava mosaic virus disease in a range of cassava cultivars in different agro-ecological regions of Uganda. Ann. Appl. Biol. 133:415-430.

Pagán, I., Alonso-Blanco, C., and García-Arenal, F. 2008. Host responses in lifehistory traits and tolerance to virus infection in Arabidopsis thaliana. PLoS Pathog 4:e1000124.

Pagán, I., Alonso-Blanco, C., and García-Arenal, F. 2009. Differential tolerance to direct and indirect density-dependent costs of viral infection in Arabidopsis thaliana. PLoS Pathog 5:e1000531.

Pagán, I., Montes, N., Milgroom, M. G., and García-Arenal, F. 2014. Vertical transmission selects for reduced virulence in a plant virus and for increased resistance in the host. PLoS Pathog 10:e1004293.

Pethybridge, S. J., and Madden, L. V. 2003. Analysis of spatio-temporal dynamics of virus spread in an Australian hop garden by stochastic modeling. Plant Dis. 87:56-62.

Polston, J. E., Chellimi, D. O., Schuster, D. J., McGovern, R. J., and Stansly, P. A. 1996. Spatial and temporal dynamics of tomato mottle geminivirus and Bemisia tabaci (Genn) in Florida tomato fields. Plant Dis. 80:1022-1028.

Power, A. G., Borer, E. T., Hosseini, P., Mitchell, C. E., and Seabloom, E. W. 2011. The community ecology of barley/cereal yellow dwarf viruses in Western US grasslands. Virus Res. 159:95-100.

Prasanna, H. C., Sinha, D. P., Rai, G. K., Krishna, R., Kashyap, S. P., Singh, N. K., Singh, M., and Malathi, V. G. 2015. Pyramiding Ty-2 and Ty-3 genes for resistance to monopartitie and bipartite tomato leaf curl viruses of India. Plant Pathol. 64:256-264.

Raccah, B., Pirone, T. P., and Madden, L. V. 1988. Correlation between the incidence of aphid species and the incidence of two nonpersistent viruses in tobacco. Agric. Ecosyst. Environ. 21:281-292.

Raymundo, A. D., and Pangga, I. B. 2011. Simulation modelling of bunchy top epidemics in a changing climate. J. Environ. Sci. Manag. 14:13-20.

Redinbaugh, M. G., Molineros, J. E., Vacha, J., Berry, S. A., Hammond, R. B., Madden, L. V., and Dorrance, A. E. 2010. Bean pod mottle virus spread in insect-feeding-resistant soybean. Plant Dis. 94:265-270.

Reynaud, B., Delatte, H., Peterschmitt, M., and Fargette, D. 2009. Effects of temperature increase on the epidemiology of three major vector-borne viruses. Eur. J. Plant Pathol. 123:269-280.

Ridley, A. W., Dhileepan, K., Johnson, K. N., Allsopp, P. G., Nutt, K. A., Walter, G. H., and Croft, B. J. 2006. Is the distribution of Fiji leaf gall in Australasian sugarcane explained by variation in the vector Perlinsiella saccharicida? Austral. Plant Pathol. 35:103-112.

Rimbaud, L., Dallot, S., Delaunay, A., Borron, S., Soubeyrand, S., Thebaud, G., and Jacquot, E. 2015a. Assessing the mismatch between incubation and latent period for vector-borne diseases: the case of Sharka. Phytopathology 105 : 1408-1416.

Rimbaud, L., Dallot, S., Gottwald, T., Decroocq, V., Jacquot, E., Soubeyrand, S. and Thebaud, G. 2015b. Sharka epidemiology and worldwide management strategies: learning lessons to optimise disease control in perennial plants. Annu. Rev. Phytopathol. 53:357-378.

Rodríguez-López, M. J., Garzo, E., Bonani, J. P., Fereres, A., Fernandez-Munoz, R., and Moriones, E. 2011. Whitefly resistance traits derived from the wild tomato Solanum pimpinellifolium affect the preference and feeding behaviour of Bemisia tabaci and reduce the spread of Tomato yellow leaf curl virus. Phytopathology 101:1191-1201

Roosien, B. K., Gomulkiewicz, R., Ingwell, L. L., Bosque-Perez, N. A., Rajabaskar, D., and Eigenbrode, S. D. 2013. Conditional vector preference aids the spread of plant pathogens: results from a model. Environ. Entomol. 42:1299-1308.

Sacristán, S., Diaz, M., Fraile, A., and García-Arenal, F. 2011. Contact transmission of Tobacco mosaic virus: a quantitative analysis of parameters relevant for virus evolution. J. Virol. 85:4974-4981.

Sacristán, S., and García-Arenal, F. 2008. The evolution of virulence and pathogenicity in plant pathogen populations. Mol. Plant Pathol. 9:369-384

Salvaudon, L., de Moraes, C. M., and Mescher, M. C. 2013. Outcomes of coinfection by two potyviruses: implications for the evolution of manipulative strategies. Proc. Royal Soc. B. 280:20122959.

Schabenberger, O., and Pierce, F. J. 2002. Contemporary Statistical Models for the Plant and Soil Sciences. CRC Press, Boca Raton, FL.

Seal, S. E., Jeger, M. J., and van den Bosch, F. 2006. Begomovirus evolution and disease management. Adv. Virus Res. 67:297-316.

Shaw, A. K., Peace, A., Power, A. G., and Bosque-Perez, N. A. 2017. Vector population growth and condition-dependent movement drive the spread of plant pathogens. Ecology 98:2145-2157.

Shi, R. Q., Zhao, H. Y., and Tang, S. Y. 2014. Global dynamic analysis of a vectorborne plant disease model. Adv. Differ. Equ. 2014:59.

Shrestha, A., Srinivasan, R., Riley, D. G., and Culbreath, A. K. 2012. Direct and indirect effects of a thrips-transmitted tospovirus on the preference and fitness of its vector, Frankliniela fusca. Entomol. Exp. Appl. 145 260-271

Sisterson, M. S. 2009. Transmission of insect-vectored pathogens: effects of vector fitness as a function of infectivity status. Environ. Entomol. 38:345-355.

Sisterson, M. S., and Stenger, D. C. 2013. Roguing with replacement in perennial crops: conditions for successful disease management. Phytopathology 103 117-128.

Sisterson, M. S., and Stenger, D. C. 2016. Disentangling effects of vector birth rate, mortality rate, and abundance on spread of plant pathogens. J. Econ. Entomol. 109:487-501

Smith, M. C., Holt, J., Kenyon, L., and Foot, C. 1998. Quantitative epidemiology of banana bunchy top virus disease and its control. Plant Pathol. 47:177-187.

Thackray, D. J., Diggle, A. J., and Jones, R. A. C. 2009. BYDV PREDICTOR: a simulation model to predict aphid arrival, epidemics of Barley yellow dwarf virus and yield losses in wheat crops in a Mediterranean-type environment. Plant Pathol. 58:186-202.

Thomas-Sharma, S., Andrade-Piera, J., Carvajal Yepes, M., Hernandez Nopsa, J. F., Jeger, M. J., Jones, R. A. C., Kromann, P., Legg, J. P., Yuen, J., Forbes, G. A., and Garrett, K. A. 2017. A risk assessment framework for seed degeneration: informing an integrated seed health strategy for vegetatively propagated crops. Phytopathology 107:1123-1135.

Thresh, J. M., ed. 2006. Plant Virus Epidemiology. Adv. Virus Res, Vol. 67 Academic Press, San Diego.

Thresh, J. M., and Cooter, R. J. 2005. Strategies for controlling cassava mosaic virus disease in Africa. Plant Pathol. 54:587-614.

Turechek, W. W., and Madden, L. V. 1999. Spatial pattern analysis of strawberry leaf blight in perennial production systems. Phytopathology 89:421-433.

Vallejo-Pérez, M. R., Télez-Ortiz, D., De La Torre Almaraz, R., López-Martinez, J. O., and Nieto-Ángel, D. 2017. Avocado sunblotch viroid: Pest risk and potential impact in México. Crop Prot. 99:118-127.

van den Bosch, F., Akudibilah, G., Seal, S., and Jeger, M. J. 2006. Host resistance and the evolutionary response of plant viruses. J. Appl. Ecol. 43:506-516.

van den Bosch, F., and de Roos, A. M. 1996. The dynamics of infectious diseases in orchards with roguing and replanting as control strategy. J. Math. Biol. 35: 129-157.

van den Bosch, F., and Jeger, M. J. 2017. The basic reproductive number of vectorborne plant virus epidemics. Virus Res. 241:196-202.

van den Bosch, F., Jeger, M. J., and Gilligan, C. A. 2007. Disease control and its selection for damaging plant virus strains in vegetatively propagated staple food crops: a theoretical assessment.Proc. Royal Soc. B. 274:11-18.

van den Bosch, F., Mc Roberts, N., van den Berg, F., and Madden, L. V. 2008. The basic reproduction number of plant pathogens: matrix approaches to complex dynamics. Phytopathology 98:239-249.

Velasco, L., Simon, B., Janssen, D., and Cenis, J. L. 2008. Incidence and progression of tomato chlorosis virus disease and tomato yellow leaf cur virus disease in tomato under different greenhouse covers in southeast Spain. Ann. Appl. Biol. 153:335-344.

Verbeek, M., van Bekkum, P. J., Dullemans, A. M., and van der Vlugt, R. A. A 2014. Torradoviruses are transmitted in a semi-persistent and stylet-borne manner by three whitefly vectors. Virus Res. 186:55-60. 
Viteri, D., and Gordillo, L. F. 2009. Modelling and control of non-persistent plant virus transmission for annual production cycles. Eur. J. Plant Pathol. 125: 435-444.

Webster, C. G., Coutts, B. A., Jones, R. A. C., Jones, M. G. K., and Wylie, S. I. 2007. Virus impact at the interface of an ancient ecosystem and a recent agroecosystem: studies on three legume-infecting potyviruses in the southwest Australian floristic region. Plant Pathol. 56:729-742.

Werner, B. J., Mowry, T. M., Bosque-Perez, N. A., Ding, H. J., and Eigenbrode, S. D. 2009. Changes in green peach aphid responses to potato leafroll virus-induced volatiles emitted during disease progression. Environ. Entomol. 38:1429-1438.

Wosula, E. N., Davis, J. A., and Clarke, C. A. 2014. Stylet penetration behaviours of Myzus persicae (Hemiptera: Aphididae) on four Ipomoea spp. infected or noninfected with sweet potato potyviruses. J. Econ. Entomol. 107:538-545.

Xu, H. X., He, X. C., Zheng, X. S., Yang, Y. J., Tian, J. C., and Lu, Z. X. 2014a. Infection of rice plants by black streaked dwarf virus improves an egg parasitoid, Anagrus nilaparvatae (Hymenoptera: Mymaridae), of rice planthoppers. Environ. Entomol. 43:1235-1239.

Xu, H. X., He, X. C., Zheng, X. S., Yang, Y. J., Tian, J. C., and Lu, Z. X. 2014b. Southern rice black-streaked dwarf virus (SRBSDV) directly affects the feeding and reproduction behaviour of its vector, Sogatella furcifera (Horvath) (Hemiptera: Delphacidae). Virol. J. 11:55.

Ye, L. F., Fu, X., and Ge, F. 2010. Elevated CO2 alleviates damage from potato virus Y infection in tobacco plants. Plant Sci. 179:219-224.
Ye, L. F., Fu, X., and Ge, F. 2012. Enhanced sensitivity to higher ozone in a pathogen-resistant tobacco cultivar. J. Exp. Bot. 63:1341-1347.

Zeilinger, A. R., and Daugherty, M. P. 2014. Vector preference and host defence against infection interact to determine disease dynamics. Oikos 123:613-622.

Zhang, X. S., and Holt, J. 2001. Mathematical models of cross protection in the epidemiology of plant virus diseases. Phytopathology 91:924-934.

Zhang, X. S., Holt, J., and Colvin, J. 2000a. Mathematical models of host plant infection by helper-dependent virus complexes: why are helper viruses always avirulent? Phytopathology 90:85-93.

Zhang, X. S., Holt, J., and Colvin, J. 2000b. A general model of plant-virus disease infection incorporating vector aggregation. Plant Pathol. 49:435-444.

Zhang, X. S., Holt, J., and Colvin, J. 2001. Synergism between plant viruses: mathematical analysis of the epidemiological implications. Plant Pathol. 50: 732-746.

Zhao, T. T., and Xiao, Y. N. 2015. Plant disease models with nonlinear impulsive cultural control strategies for vegetatively propagated plants. Math. Comput. Simul. 107:61-91.

Zhou, F. Y., and Yao, H. X. 2014a. Dynamics and biocontrol: the indirect effects of a predator population on a host-vector disease model. Abstr. Appl. Anal. 2014: 252718. http://dx.doi.org/10.1155/2014/252718

Zhou, F. Y., and Yao, H. X. 2014b. Global dynamics of a host-vector-predator mathematical model. J. Appl. Math. 2014:245650. http://dx.doi.org/10.1155/ $2014 / 245650$ 